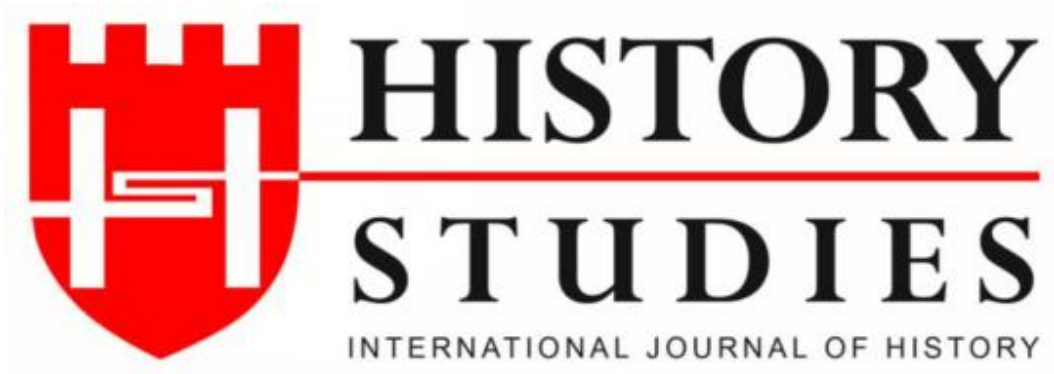

\author{
ISSN: 13094173 (Online) 1309 - 4688 (Print) \\ Volume 10 Issue 8, p. 19-48, November 2018 \\ DOI Number: 10.9737/hist.2018.662
}

\title{
Nil Savași
}

The Battle of the Nile

\author{
Doç. Dr. Yahya BAĞÇECI \\ (ORCID: 0000-0001-8595-1953) \\ Erciyes Üniversitesi - Kayseri
}

Öz: 1793 yılında başlayan Koalisyon Savaşları, Fransa'yl, Avrupa'nın pek çok devletiyle karşı karşıya getirdi. Bunlardan belki de en önemlisi Fransa'nın müzmin rakibi Ingiltere'ydi. Donanması ve tüm zenginlik kaynaklarl, onu yenilmesi zor bir düssman haline getiriyordu. Fransı yönetimine göre, Ada'ya yönelik ani bir baskın harekâtı bu düşmanı saf dışı bırakmanın en iyi yoluydu. Ancak bu plana, askerî başarıları sayesinde oldukça ünlenen Napolyon Bonapart karşı çıktı. İngilizlerin denizlerdeki hâkimiyetinin, bir istila harekâtını ümitsiz bıraktığını düşünen bu genç komutanın planı ise Mısır'ı alarak Ingiltere'yi tüm servet kaynaklarından mahrum bırakmaktı. Bu sayede Doğu'yu fethetmekle ilgili hayalini de uygulamaya geçirebilirdi. Nitekim bu amaçla hazırlanan Fransız Donanması, Ingilizleri atlatıp Osmanlı toprağı olan Mısır'a ulaşmayı başardı. Buna karşı Ingiliz Amiral Nelson, Fransız Donanması'nı bulmak ve imha etmek üzere görevlendirildi. Nelson, uzun arayışlarının akabinde, Nil Nehri'nin ă̆zına yakın bir yerde bulunan Ebukır Koyu'nda Fransız Donanması'nı demirli vaziyette buldu. Fransız Komutan Amiral Brueys, muhtemel bir saldırlya karşı gerekli tedbirleri aldığını düşünüyordu. Üstelik Fransı Donanması saylsal anlamda oldukça üstün görünüyordu. Ancak Fransızların bu üstünlükleri, Nelson'u harekete geçmekten alıkoymadı. 1 Ağustos 1798'de yaşanan Nil Deniz Savaşı, Nelson'un uyguladığı askerî taktik sayesinde Ingilizlerin zaferiyle sonuçlandı. Bu zafer, İngilizlerin denizlerdeki hâkimiyetini kesinleştirdiği gibi, Napolyon'un Mısır istilasını da başarısızlı̆̆a mahkûm etti.

Anahtar Kelimeler: Ingiltere, Fransa, Osmanll, Misir, Napolyon Bonapart, Amiral Nelson, Amiral Brueys.

Abstract: The Coalition Wars, which began in 1793, confronted France with many states in Europe. Perhaps the most important of these was England, France's long-standing opponent. Their fleet and all the resources of wealth made them a difficult enemy to defeat. According to the French administration, a sudden raid on the Island was the best way to get rid of this enemy. However, Napoleon Bonaparte, who was quite famous for his military achievements, opposed this plan. The plan of that young commander, who thought that the English domination of the seas left an idea of invasion in despair, was to capture Egypt thus depriving England of all wealth resources. By this way, he could also put his dream of conquering the East into practice. As a matter of fact, the French Navy prepared for this purpose succeeded in reaching the Ottoman land of Egypt by surpassing the English navy. In response, British Admiral Nelson was assigned to find and destroy the French Navy. Nelson found the French Navy anchored in Aboukir Bay, near the estuary of the Nile, after long searches. French Commander Admiral Brueys thought he had taken the necessary precautions against a possible attack. Moreover, the French Navy seemed quite superior in numerical sense. But the French's superiority did not prevent Nelson from taking action. The Naval Battle of the Nile, which took place on August 1, 1798, ended with the victory of the British thanks to the military tactic Nelson practiced. This victory has proved Napoleon's Egypt invasion unsuccessful, thus consolidating British domination over the seas.

Keywords: England, France, Ottoman, Egypt, Napoleon Bonaparte, Admiral Nelson, Admiral Brueys. 


\section{Giriş}

Nil Savaşı, hem İngiliz hem de Fransız Tarihi açısından ayrı bir öneme sahiptir. Bununla beraber Napolyon Bonapart'ın Mısır macerasının bir sonucu olarak ortaya çıkan bu deniz savaşının Fransızlara kıyasla İngilizler açısından daha fazla önemli görüldügü düşünülebilir. Şöyle ki 1798 Mayısı'nda Toulon'dan ayrılan Napolyon, bir sonraki yılın Ekim ayına kadar Fransa'dan uzak kaldı. Bu süreçte Fransa' da yönetimde bulunan direktörler, Napolyon'u kendi politikası ve kaderiyle baş başa bıraktılar. Fransız yönetiminin Bonapart'ı yalnız bırakmasına, İngiltere'nin ise bilakis bu işin çok büyük bir parçası haline gelmesine bakılırsa, Mısır Seferi'nin ve bu seferin neticesini ciddi şekilde etkileyecek olan bu savaşın İngilizler açısından daha çok önemsendiği görülür. ${ }^{1}$

Şüphesiz Türk Tarihi açısından da bu savaş önem arzetmektedir. Zira Fransa ile İngiltere arasındaki rekabetin bir sonucu olarak gündeme gelen askerî seferin hedefinde yer alan Mısır'ın asıl sahibi Osmanlı Devleti'ydi. Ancak Fransızlar, Akdeniz hâkimiyetinde önemli bir avantaj elde etmek üzere bu topraklara saldırırken, Osmanlı Devleti'yle sürdürdükleri barışçıl ilişkileri bir tarafa koymakta tereddüt göstermediler. Nil Savaşı'nda Fransızlara vurulan darbe ise, kendi topraklarını savunmaktan başka bir gayesi olmayan Osmanlı Devleti için oldukça yararlı oldu.

1798 tarihli bu kritik deniz savaşının nedenlerini ve sonuçlarını anlayabilmek için, Koalisyon Savaşları içerisinde İngiliz-Fransız rekabetine ve özellikle de Fransa'da sivrilmeye başlayan Napolyon'un hedeflerine bakmak gerekir.

\section{Napolyon'un Doğu İle İlgili Planları}

Napolyon Bonapart' $1 n^{2}$ 1797'den sonraki 18 yıllık hikâyesi, aynı zamanda Avrupa'nın da hikâyesidir. Zira sahip olduğu üstün askerî meziyetlerin yardımıyla Fransa'nın başına geçip despotik bir yönetim kuran Napolyon, yalnızca Fransa topraklaryyla yetinmedi, Avrupa Kıtası'nın tüm batısını ya ilhak etti ya da buradaki ülkeleri kendi vasalları haline getirdi. ${ }^{3}$

Tüm Avrupa'nın kaderinde belirleyici bir rol oynayan Napolyon'un yıldızı ise, Fransız İhtilali sonrası yaşanan savaşlar sırasında parlamaya başladı. Ünü, özellikle İtalya'yı ele geçirmesinin akabinde oldukça arttı. I. Koalisyon Savaşları sırasında Avusturya'yı yenilgiye uğratan ordunun başkomutanıydı. Fransa'nın önemli kazançlar elde ettiği 1797 tarihli Campo Formio Barış Antlaşması'nın da mimarıydı. ${ }^{4}$ Nitekim bu antlaşma ile Fransa, I. Koalisyon'u oluşturan devletlerin hemen hepsini saf dışı bırakmış oldu.

I. Koalisyon dağıldıktan sonra yalnızca İngiltere, Fransa'ya karşı koymaya devam etti. ${ }^{5}$ Ama belirtmek gerekir ki donanması, sömürgeleri, Hindistan'daki hâkimiyeti ve tüm zenginlik

\footnotetext{
${ }^{1}$ Eyre Evans Crowe, The History of France, Vol. V, Longmans, Green and Co., London 1868, s. 47.

${ }^{2}$ Korsika doğumlu olan Napolyon, İtalyan bir aileye mensuptu. Fransa ordusunda topçuluk eğitimi aldı. Cumhuriyet idaresinde ve savaş şartlarında kısa sürede yükselmesini bildi. Edith Thompson, History of England, James Campbell and Son, Toronto 1878, s. 303.

${ }^{3}$ Age, s. 302-303.

${ }^{4}$ Edward Gleichen, France: The Nations of Today, A New History of the World, Edited by John Buchan, Hodder and Stoughton, London 1923, s. 74.

51798 Nisanı'ndan sonra İngiliz Hükümeti'nin politikası, İngilizlerin savaşlar sırasında ele geçirdikleri yerleri ellerinde tutmasına imkân vermeyen bir barışa razı olmamak kararlığı üzerine kuruluydu. Aslında bu politikanın temeli Fransa'nın karasal kazanımlarıyla denge kurulması gerekliliği teorisi üzerine dayanıyordu. Ephraim Douglass Adams, The Influence of Grenville on Pitt's Foreign Policy 1787-1798, Carnegie Institution of Washington, Washington 1904, s. 72-73.
} 
kaynakları onu, Fransa Cumhuriyeti'nin gerçekten de yenilmesi zor bir düşmanı haline getirmekteydi. Dahası İngiltere, Fransız kraliyet taraftarlarının ve hatta direktörler yönetiminin tüm düşmanlarının daima sığındıkları bir ülkeydi. Bu nedenlerle Fransız yönetimi, İngiltere’ye yönelik bir saldırının planlarının hazırlanması emrini verdi. ${ }^{6}$

Nitekim İngiltere'ye ani bir baskın yapmak amacıyla Fransız kıyılarında büyük bir ordu hazırlanmaya başland1. ${ }^{7}$ Napolyon'un adı ise bu ordunun başkomutanı olarak geçiyordu. Ancak ona göre, yapılan hazırlıklar oldukça yetersizdi ve bu nedenle de İngiliz sahillerine düzenlenecek böyle bir taarruzun başarıya ulaşması imkânsız görünüyordu. ${ }^{8}$ Zaten bu sıralarda Napolyon'un ilgisi Doğu'ya yönelmişti. ${ }^{9}$ Doğu'nun cazibesi, Büyük İskender'i karşı konulmaz bir şekilde kendisine çektiği gibi, şimdi de bu hayalperest genç Korsikalı'yı çekiyordu. Bu küçük Avrupa ona yeterli gelmiyordu. ${ }^{10}$ Aklında ise, sadece en samimi arkadaşlarıyla paylaştığı daha ciddi, daha cüretkâr ve daha çekici bir proje mevcuttu: "Kalıp beklemek istemiyorum. Burada yapacak bir şey yok. Hiç dinlemiyorlar. Kalırsam yakın zamanda tükeneceğimi görüyorum. Buradaki herşey şimdiden tükenmiş durumda. Daha fazla kazanacă̆ım şan ve haşmet yok. Bu küçük Avrupa yeterince şan ve haşmet vermiyor. En yüksek şan ve haşmetin doğum yeri olan Doğu'ya gitmeliyim. İngiltere'ye karşı başarılı bir taarruz şüpheli görünüyorsa ki korkarım öyle, bu durumda Ingiltere'ye karşı hazırlanan ordu Doğu için hazırlanan ordu haline gelecek. Bu nedenle Misır'a gitmeliyim."11

Napolyon'un amac1, Malta ve Mısır'1 alarak Fransa'nın en büyük rakibi olan İngiltere'yi tüm servet kaynaklarından mahrum bırakmaktı. Zira İngilizlerin denizlerdeki hâkimiyeti, bu ada devletine karşı yapılacak bir istila hareketini gerçekten de ümitsiz bırakıyordu. Bununla beraber istila tehdidinin sürdürülmesi İngiliz Donanması'nın bölgeden uzaklaşmasına engel olabilirdi. ${ }^{12}$ Napolyon, bir taraftan İngiliz İmparatorluğu'nun merkezini korkuturken, diğer taraftan Hindistan'daki yerleşimine Mısır vasıtasıyla bir darbe vurmayı tasarlıyordu. ${ }^{13}$ Mısır, İngiltere'ye ait değildi; ama Hindistan'a giden yol üzerinde bulunuyordu. Napolyon, pek çok

${ }^{6}$ Gleichen, age, s. 74. İngiltere'ye karşı yapılacak doğrudan bir saldırı, bir yüzyıldan fazla bir süredir Fransız savaş politikasında yer alan bir tasavvurdu. Ancak Kraliyet Donanması, bu düşüncenin hayata geçirilmesi önündeki en önemli engel olarak her zaman varlığını koruyordu. Brian Lavery, Nelson and the Nile: The Naval War Against Bonaparte 1798, Caxton Editions, UK 2003, s. 12.

${ }^{7}$ Aslında daha önce İtalya'da zafer kazanmıș olan ordu, şimdi yeniden İngiltere'ye karşı tanzim edildi. James Franck Bright, A History of England, Period III, Constitutional Monarchy William and Mary to William IV. 1689. 1837, E. P. Dutton and Co., New York 1889, s. 1219.

${ }^{8}$ Napolyon, daha 1798 başlarında, özellikle İhtilal nedeniyle donanmanın iyice yıpranmış olmasından dolayı böyle bir istila hareketinin imkânsız olduğunu gördü. Gleichen, age, s. 74. 23 Şubat'ta direktörlere yazdı̆̆ bir raporda şu değerlendirmede bulundu; "Ne kadar çaba göstersek de birkaç yll içerisinde denizlerde üstünlük kazanamayacağız. Denizlere hâkim olmadan İniltere üzerine düzenlenecek bir baskından olumlu sonuç elde etmek ise oldukça zordur." Lavery, age, s. 9. Napolyon haklıydı. Gerçekten de İhtilal, Fransız Donanması'nı oldukça olumsuz şekilde etkiledi. Aristokratların soyundan gelen pek çok subay giyotine gönderildi, pek çoğu ise Fransa'dan ayrılarak hayatlarını kurtarabildi. Hem tecrübeli denizci sayısındaki düşüş hem de ekonomik sıkıntılar üstesinden gelinmesi gereken ciddi sorunlard. Nicholas Blake, Richard Lawrence, The Illustrated Companion to Nelson's Navy, Stackpole Books, 2005, s. 48. Bununla beraber Mısır'ın işgaliyle İngiliz Donanması Akdeniz'e çekilip orada oyalanabilirse, belki o zaman Londra'ya bir saldırı mümkün olabilirdi. Gleichen, age, s. 74.

9 Aslında Napolyon, gençlik günlerinden itibaren Doğu'nun gizemine karşı ciddi derecede bir merak ve ilgi duyuyordu. Gleichen, age, s. 74. Üstelik Campo Formio Antlaşması'yla zirveye varan askerî başarısı, Napolyon'a, şanını sürdürmek üzere yönelecek Doğu'dan başka bir yer de bırakmıyordu. Edward W. Said, Şarkiyatçılık, Batı'nın Sark Anlayışları, Çeviren: Berna Ülner, Metis Yayınları, İstanbul 1999, s. 89.

${ }^{10}$ Charles Downer Hazen, The French Revolution and Napoleon, Henry Holt and Company, New York 1917, s. 253.

${ }^{11}$ M. Guizot, Madame Guizot De Witt, France, Translated By Robert Black, Vol. VI, Peter Fenelon Collier \& Son, New York 1900, s. 372.

${ }^{12}$ Cecil Headlam, The Making of Nations France, Adam \& Charles Black, London 1913, s. 366.

${ }^{13}$ William Grimshaw, History of England, Grigg, Elliot \& Co., Philadelphia 1847, s. 252. 
muasırı gibi, İngiltere'nin gücünü İngiliz kaynaklarından ve fabrikalarından ya da İngiliz aklından ve karakterinden değil, Hindistan'ın inanılmaz zenginliğinden aldığ Eğer İngiltere'nin Hindistan'la bağlantısı kesilirse bu kuvvet sarsılır ve çökerdi. ${ }^{14}$

$\mathrm{Bu}$ düşüncelere sahip olan Napolyon, İngiltere'yi istila amacıyla hazırlanan ordunun başına geçmesi için direktörler tarafından yapılan teklifi reddetmekle kalmayıp, sadece İngilizlerin ticaretini tehdit etmek için değil; ama aynı zamanda Doğu'yu fethetmekle ilgili hayalini gerçekleştirmek için bir adım olacak olan Mısır Seferi konusunda resmi müsaadeyi elde etmek üzere girişimlerde bulunmaya başlad. ${ }^{15}$ Nitekim Napolyon'un bu fikri, 1797'nin Temmuz ayında Dışişleri Bakanlığı'na getirilen Talleyrand tarafindan uygun bulundu. Her ikisi tarafından 5 Mart 1798'de resmen teklif edildiği zaman, bu düşünce direktörlere de çekici geldi. Zira Mısır'a düzenlenecek bir sefer, İngiltere'ye yapılacak geniş kapsamlı bir askerî baskın hareketinden daha küçük ölçekli ve daha ucuz olacaktı. Sefer başarılı olursa, Hindistan'a giden yol kontrol altına alınabilirdi. Bu durumda ise, Hindistan'ın zenginliklerine fazlasıyla bağımlı olan İngiltere'nin savaş dışı kalması kuvvetle muhtemel görünüyordu. ${ }^{16}$ Aynı zamanda Akdeniz hâkimiyeti açısından da çok önemli bir adım atılmış olacaktı. 1768'de Korsika'yı alan Fransa, son olarak 1797'de Korfu'ya yerleşti. Malta ve Mısır'ı ele geçirmesi durumunda ise gerçekten Akdeniz'de önemli bir güç haline gelebilirdi. Yakın bir zaman önce Karayip İmparatorluğu'nu kaybetmiş olan Fransa, şimdi bu şekilde başka bir yerde yeni bir tanesini kurabilirdi. Bu durum ise, Ümit Burnu'na sahip olan İngiltere'yle arasında bir denge sağlayabilirdi. Ayrıca belirtmek gerekir ki direktörler açısından Mısır Seferi, savaşa olan ihtiyacı da karşılamış olacaktı. Zira İhtilal, savaş bağımlısı haline gelmiş gibi görünüyordu. Ancak Avrupa anakarasında gerçek bir düşman kalmamıştı. ${ }^{17}$ Diğer durumda, yani seferin başarısız olması halinde ise, direktörler, en azından Napolyon'dan kurtulmuş olacaklardı. Gerçekten de direktörlerin Misır'ı istila fikrini kabul etmelerinde, tehlikeli bir rakip olarak gördükleri Napolyon'u Paris'ten uzaklaştırma arzularının çok büyük bir payı olduğuna hiç şüphe yoktu. ${ }^{18}$ Potansiyel tehlikeye sahip ${ }^{19}$ bu politik figürün Paris'ten uzaklaştırılacak olmasından dolayı duydukları memnuniyet, orduyu oldukça uzağa gönderecek olmalarından dolayı duydukları endişenin önüne geçti. ${ }^{20}$ Nitekim bu sebeplerle direktörler, Mısır projesini destekleme konusunda tereddüt göstermediler. İngiltere'yle başlayan barış görüşmeleri ise bu nedenle kesildi. ${ }^{21}$

\section{Mısır Seferi Hazırlıkları}

Napolyon'un Mısır ve Doğu ile ilgili tasarılarını hayata geçirmek üzere 1798 baharında Toulon ve Marsilya limanlarında askerî hazırlıklar başladı. ${ }^{22}$ Komutasına Koramiral François Paul d'Aiguilliers Brueys'in getirildiği Fransız Donanması'nda 13 savaş gemisi ile yüzlerce nakliye gemisi bulunuyordu. İçlerinde, generalleri Bonapart'ın bildirisi ile heyecanlanmış kırk bine yakın asker mevcuttu" : "Askerler, sizler Ingiltere'ye karşı hazırlanan ordunun

\footnotetext{
${ }^{14}$ Hazen, age, s. 251.

${ }^{15}$ Headlam, age, s. 365.

${ }^{16}$ William Doyle, The Oxford History of the French Revolution, Oxford University Press, Oxford 1989, s. 332.

${ }^{17}$ Lavery, age, s. 12.

${ }^{18}$ William Henley Jervis, A History of France, Harper \& Brothers, New York 1876, s. 587; Emile de Bonnechose, France, Vol. IX, Revised and Edited by Fred Morrow Fling, The H. W. Snow and Son Company, Chicago 1910, s. 305.

${ }^{19}$ Napolyon, İtalya'dan döndüğünden beri mütevazı bir şekilde hareket ediyordu. Ama bu durum direktörlerin kendisini önemli bir tehdit olarak görmelerine engel olmadi. Doyle, age, s. 332.

${ }^{20}$ Sylvia Neely, A Concise History of the French Revolution, Rowman \& Littlefield, Plymouth 2008, s. 240.

${ }^{21}$ Headlam, age, s. 365.

22 Clive Emsley, Britain and French Revolution, Routledge, Abingdon Oxon 2014, s. 57.

${ }^{23}$ Toulon'dan ayrılan Fransız Donanması'nda yer alan gemilerin cinsleri, miktarı ve mevcudu hakkında Fransız ve
} 
kollarından birisisiniz. Sizler, dağlarda, ovalarda ve şehir kuşatmalarında savaştınız. Sizin için geriye denizlerde savaşmak kaldl... Askerler, Avrupa'nın gözleri sizin üzerinizde. Gerçekleştirmeniz gereken çok büyük bir kaderiniz var. Söz verdiğiniz savaşlar, alt etmeniz gereken tehlikeler ve üstesinden gelmeniz gereken meşakkatler var. Ülkenizin ve insanliğın refahı ve kendi şan ve şerefiniz için şimdiye kadar yaptıklarınızdan daha fazlasını yapacaksınız. Askerler, denizciler, piyadeler, topçular, süvariler, bir olun! Unutmayın ki savaş günü birbirinize ihtiyacını olacak... Askerler, denizciler, şimdiye kadar ihmal edildiniz. Bugün Cumhuriyet' in en çok merak ve endişe ettiği şey sizlersiniz. Parçası olduğunuz ordunun kıymetlisi olacaksınız. Doğumuyla Avrupa'nın hakemi olan Cumhuriyet'i var eden hürriyet ruhu, denizlerin ve en uzak ülkelerin de hakemi olacaktır." ${ }^{24}$

Napolyon'un maiyetinde pek çok tecrübeli Fransız askeri vardı. Ayrıca binlerce İtalyan askeri de bu orduya dâhil edildi. ${ }^{25}$ Asker sayısıyla orantılı miktarda at, top, erzak ve askerî malzemeler de gemilere yüklendi. ${ }^{26}$ Büyük bir koloni tesis etmek ve Mısır hakkında araştırma yapmak için gerekli olacak çok sayıda sanatkâr, doğa bilimcisi, coğrafya uzmanı ile başka alanlarda çalışan birçok bilim insanı da orduya eşlik ediyordu. ${ }^{27}$ Askerler ise son ana kadar gidecekleri yerden ve amaçlarından habersizdiler. ${ }^{28}$ Aslında tüm hazırlıklar gizlilik içerisinde yürütülmeye çalışıldı. ${ }^{29}$ Ancak Fransızların bir sefer için hazırlandıkları kimsenin gözünden kaçmadı. Nitekim tüm Avrupa, bu hazırlıkların hedefinin neresi olabileceği ile ilgili

İngiliz kaynaklarında farklı rakamlar verilmektedir. Mesela Clarke ve McArthur'a göre, Fransız Donanması'nda, 10 firkateyn, 20 gambot, birkaç brik ve tek yelkenli gemiyle beraber 40 bin askerin yer aldığ 1280 nakliye gemisi bulunuyordu. James Stanier Clarke, John McArthur, The Life of Admiral Lord Nelson, K. B.; From His Lordship's Manuscripts, Printed by T. Bensley for T. Cadell and W. Davies, London 1810, s. 462. Baines de, Frans1z ordusunun mevcudu ile ilgili olarak aynı sayıyı vermiştir. Edward Baines, History of the Wars of the French Revolution from the Breaking out of the War in 1792 to the Restoration of a General Peace in 1815; Comprehending the Civil History of Great Britain and France during that Period, Vol. I, Printed for Longman, Hurst, Rees, Orme and Brown, London 1817, s. 202. Barker, Fransız Donanması'nda yer alan gemi mevcudunu 13 savaş gemisi, 7 firkateyn, 24 daha küçük çapta gemi ile 200 nakliye gemisi olarak göstermiștir. Matthew Henry Barker, The Life of Nelson Revised and Illustrated, With Original Anecdotes, Notes, Etc., Frederic Shoberl, London 1836, s. 183. Hughes da, Barker gibi savaş gemisi sayısını 13 ve firkateyn sayısını da 7 olarak belirtmiştir. Küçük gemilerle beraber toplam yelkenli gemi sayısını ise 44 olarak vermiştir. Ayrıca içlerinde 20 bin asker taşıyan 200 kadar da nakliye gemisi olduğunu söylemiştir. Thomas Smart Hughes, The History of England From the Accession of George III. 1760 to the Accession of Queen Victoria 1837, Vol. VI, Third Edition, George Bell, London 1846, s. 349. Grimshaw da, sadece 20 bin asker mevcudundan bahsetmiştir. Grimshaw, age, s. 252-253. Muhtemelen firkateynleri de savaş gemisi olarak addeden Jervis, savaş gemisi sayısını 20 ve Fransız Donanması'nın mevcudunu da 36 bin olarak göstermiştir. Jervis, age, s. 587. Bright da ordunun miktarıyla ilgili olarak aynı rakamı vermiştir. Donanma mevcudu hakkında ise, 30 savaş gemisinin refakatinde daha küçük 72 gemi ile 400 askeri nakliye gemisinin bulunduğunu söylemiştir. Bright, age, Period III, s. 1220. Green ise, Napolyon'un 30.000 tecrübeli askerle yola koyulduğundan bahsetmiştir. John Richard Green, World's Best Histories England, With a Supplementary Chapter of Recent Events by Julian Hawthorne, Vol. IV, Co-operative Publication Society, New York and London, 1898, s. 336. Guizot ile Witt ise, 13 Fransız ve 2 Venedik savaş gemisiyle 40 firkateyn ve 400 nakliye gemisinden oluştuğunu söyledikleri Fransız Donanması'ndaki asker sayısını 50 bin olarak göstermişlerdir. Guizot; Witt, age, Vol. VI, s. 380. Heffernan'a göre ise Fransızların asker sayıs1 36 bindir. Michael Heffernan, "France and the Wider World", Revolutionary France 1788-1880, The Short Oxford History of France, Edited by Malcolm Crook, Oxford University Press, New York 2002, s. 182.

${ }^{24}$ Guizot; Witt, age, Vol. VI, s. 380-381.

${ }^{25}$ Rapin de Thoyras, The History of England from the Earliest Periods, Vol. II, Translated, Corrected and Revised and Continued to the Present Time by Henry Robertson, Albion Press, Printed for J. and J. Cundee, London 1820, s. 611.

${ }^{26}$ Hughes, age, Vol. VI, s. 349.

${ }^{27}$ Grimshaw, age, s. 253; Jervis, age, s. 587. Napolyon, Mısır'ın tümünü almakta kararlıydı. Bu amaçla yaptırdığı ön hazırlık görülmedik büyüklükteydi. Ama bu hazırlığın neredeyse bağnazca şematik, tertipçi ve deyim yerindeyse metinsel hazırlıklardan ibaret olduğunu da söylemek gerekir. Said, age, 89.

${ }^{28}$ Guizot; Witt, age, Vol. VI, s. 381.

${ }^{29}$ Hazen, age, s. 253. 
düşüncelere daldi. ${ }^{30}$

Sonunda Napolyon, kafası Doğu'da muhteşem bir imparatorluk meydana getirme hayalleriyle dolu bir şekilde, 19 Mayıs’ta Mısır Seferi için hareket emrini verdi. ${ }^{31}$

\section{3. İngiltere'nin Sefere Engel Olma Çabaları}

Fransızların, İngiltere aleyhine harekete geçmeye hazırlandıklarına şüphe yoktu. Aslında İngilizler de, böyle bir saldırı ihtimalinin farkındaydılar. ${ }^{32}$ Napolyon'un hedefinin Fransız orduları tarafından son iki yılda iki defa istila edilmek istenen İrlanda olabileceği düşünülüyordu. Bu tehlike karşısında Akdeniz'i, özellikle de Toulon'u kontrol altında tutmak son derece önem arz ediyordu. Ancak İngiliz Donanması'nın önemli bir kısmı, Büyük Okyanus sahilinde Cebelitarık'a yakın bir konumda yer alan Cadiz'e yapılan kuşatmayla meşguldü. ${ }^{33}$ Ayrıca, başarılı bir komutan olan Koramiral Horatio Nelson'a ${ }^{34}$ da, Cadiz'deki İngiliz Donanması'na destek vermesi için emir verilmişti. 9 Nisan'da St. Helens'den yola çıkan Nelson, 29'unda Lord St. Vincent'ın komutasındaki İngiliz Donanması'na katıldı. Bu sırada Fransızların Toulon'daki askerî hazırlıklarıyla ilgili söylentiler de arttı. Bu sefer de Nelson, bu hazırlıkları araştırmak ve gerekli tedbirleri almak üzere emir aldı. 9 Mayıs'ta Cebelitarık'tan hareket eden Nelson'un komutası altına Vanguard, Orion ve Alexander adlı savaş gemileri, Caroline, Flora, Emerald ve Terpsichore adlı firkateynler ile yalnız bir güvertesinde savaş topları bulunan tek direkli bir yelken gemisi verildi. ${ }^{35}$

Nelson, üstün meziyetlere ${ }^{36}$ sahip bir kumandandı. Özellikle zafer için duyduğu arzuyla kendi mürettebatını heyecanlandırma ve sonunda da zaferi sağlamada oldukça yetenekliydi. ${ }^{37}$

\footnotetext{
${ }^{30}$ Baines, age, Vol. I, s. 202; Thoyras, age, Vol. II, s. 611.

${ }^{31}$ Thompson, age, s. 303.

${ }^{32}$ Gleichen, age, s. 74. Gerçekten de İngilizler'de, Fransızların kendilerine saldıracaklarına dair bir korku vardı. Onlara göre, "Fransızların üstünlüklerini ve hâkimiyetlerini artırmak için yaptıkları tüm karanlık planların hedefi, en korkunç düşman olarak gördükleri İngiltere'ydi. Yenileyip güçlendirdikleri ordulartyla Adriyatik'ten Kuzey Denizi'ne kadar oldukça geniş bir cumhuriyet oluşturmak ve tüm Avrupa'yı Ingiltere'ye karşı bir koalisyon altında birleştirmek niyetindeydiler. Akdeniz bir Fransız gölü haline gelecekti. Her liman İngiliz gemilerine kapatılacaktı. Ingiltere'nin ticareti mahvedilecek ve kibri kırılacaktı. O'nu daha hızlı bir şekilde itaatkâr hale getirmek için ise, sisli bir gecede İngiliz filosu tarafindan gözetlenemeyen Kanal üzerinden bir ordu karşlya geçirilebilirdi." William Hunt, The History of England from the Accession of George III to the Close of Pitt's First Administration (17601801), Longmans, Green, and Co., London, New York and Bombay 1905, s. 401.

${ }^{33}$ Guizot; Witt, age, Vol. VI, s. 381.

${ }^{34}$ Nelson, 29 Eylül 1758'de Kuzey Norfolk'daki Burnham Thorpe'da dünyaya geldi. Babası Reverend Edmund Nelson, İngiliz Kilisesi rahiplerindendi. Edmundlar, orta sınıfa mensup olsalar da, iyi eğitim görmüş, yükselme ihtirası olmayan, Burnham'daki papaz evinde sakin ve huzurlu bir yaşam süren insanlardı. Nelson'un yükselmesini sağlayacak firsatları ise, eşinin ailesinin geniş çevresi sağladı. Zira Catherine Suckling'in güçlü Walpole ailesiyle ilişkisi vardı. Catherine, ilk Britanya Başbakanı Sir Robert Walpole'ün (sonrasında Lord Orford) küçük yeğeniydi. $\mathrm{Bu}$ aile aynı zamanda Nelsonların komşularıydı. Ancak onlara kıyasla çok daha zengin ve üst sınıfa mensup bir aileydi. Nitekim Nelsonların Burnham'da yaşamalarını sağlayan da, Walpolelerle olan bu ilişkileriydi. Andrew Lambert, Nelson: Britannia's God of War, Faber \& Faber, 2010, s. 2.

${ }^{35}$ Clarke; McArthur, age, s. 451-453; Barker, age, s. 182-183; Alfred Thayer Mahan, The Life of Nelson: The Embodiment of the Sea Power of Great Britain, Vol. I, Sampson Low, Marston \& Company, London 1897, s. 321323; Robert Southey, The Life of Horatio Lord Nelson, J. M. Dent \& Co., E. P. Dutton \& Co., London and New York 1906, s. 102-103.

${ }^{36}$ İngilizler, bir soruna ustaca gösterilen yaklaşım anlamında kendisinin yeteneklerine gönderme yaptıkları, “Nelson dokunuşu" tabirini kullanırlar. https://en.oxforddictionaries.com/definition/nelson_touch

${ }^{37}$ Kathleen Wilson, "Nelson, and the People: Manliness, Patriotism and Body Politics", Admiral Lord Nelson: Context and Legacy, Edited by David Cannadine, Palgrave Macmillan, Hampshire and New York 2005, s. 59. Nitekim cesareti, düşmanları yok etmedeki katı kararlılı̆̆ı, kendisini görevine adaması ve emrindekileri anlaması, Nelson'u İngilizler açısından örnek bir deniz kuvvetleri komutanı haline getirecekti. Naval Leadership and Management, 1650-1950: Essays in Honour of Michael Duffy, Edited by Helen Doe and Richard Harding, Boydell Press, UK 2012, s. 16. 
Ancak Toulon hazırlıklarını takip etmesi ve gerekli tedbirleri alması için emrine sadece 74 topluk üç savaş gemisiyle dört fırkateyn verilmişti. ${ }^{38}$ Üstelik bu küçük donanma, abluka görevine başladıktan sonra kıyıdan denize doğru esen güçlü kuzey rüzgârlarına maruz kalmıştı. ${ }^{39}$ Nitekim İngiliz gemileri, Toulon'a varmalarının hemen akabinde, çıkan bir firtına sonucunda sahilden oldukça uzağa sürüklendi. Bu firtınada Nelson'un filosu ciddi şekilde hasar gördü. ${ }^{40} \mathrm{O}$ da, Sardunya limanı San Pietro’ya çekildi ve gemilerinin tamiriyle meşgul olmaya başladi. ${ }^{41}$

$\mathrm{Bu}$ gelişme tam da Fransızların istedikleri firsat oldu. Şartlar Akdeniz'e açılmak için müsait görünüyordu. Fransız limanlarını kontrol görevini üstlenen Nelson ortalıkta yoktu. Bu durumdan yararlanmasını bilen Fransız Donanması, 19 Mayıs'ta harekete geçti ve İngilizlere yakalanmadan bölgeden hızlı bir şekilde ayrılmayı başardı. ${ }^{42}$

Fransız Donanması'nın hareket ettiği haberi geldiğinde Cadiz'de bulunan Lord St. Vincent, tüm donanmanın Akdeniz'e geçmesi emrini verdi. Nelson ise zaten Akdeniz'deydi. ${ }^{43}$ Nitekim Fransız Donanması'nı bulma görevi de ona verildi. ${ }^{44} \mathrm{St}$. Vincent, kendisine en iyilerinden 10 adet $74^{\prime}$ 'lük savaş gemisiyle bir adet 50 'lik firkateyn gönderdi. ${ }^{45}$ Nelson da, denize açılmış olan Fransız Donanması'nı durdurabilmek için daha fazla vakit kaybetmeden harekete geçti. ${ }^{46}$ Aslında tüm bu yaşananlar, İngilizlerin Toulon'u abluka altına alma veya bu sefere baştan engel olma konusunda yeterince hazırlıklı olmadıklarını gösteriyordu. ${ }^{47}$

Hem İngiliz Hükümeti, hem de Doğu Hindistan İdaresi, Napolyon'un seferiyle ilgili olarak gelen ilk haberler üzerine oldukça telaşlandı. İngiltere'nin Hindistan Genel Valisi Lord Wellesley, Kızıl Deniz'den yapılabilecek muhtemel bir saldırı ihtimaline karşı uyarıldı. ${ }^{48}$ Hindistan'daki kuvvetleri takviye etmek amacıyla da 4 bin mevcutlu bir askerî birlik hızlı bir şekilde yola çıkarıldı. ${ }^{49}$

Napolyon'un Toulon'dan Malta'ya varması ise yaklaşık 20 gün sürdü. ${ }^{50}$ Zapt edilemez bir yer olarak düşünülen Malta Adası kolay bir şekilde ele geçirildi. ${ }^{51}$ Şövalyelerin yaptıkları

${ }^{38}$ Hughes, age, Vol. VI, s. 350.

${ }^{39}$ Charles Edmund Carrington, John Hampden Jackson, A History of England, Cambridge University Press, Cambridge 1932, s. 572-573.

${ }^{40}$ Nelson against Napoleon: From the Nile to Copenhagen, 1798-1801, Edited by Robert Gardiner, Caxton Editions, London 2001, s. 13. Nelson'un emri altındaki gemiler içerisinde firtınadan en fazla zarar göreni Vanguard oldu. Barker, age, s. 184-185.

${ }^{41}$ Hughes, age, Vol. VI, s. 350; Cassell's Illustrated History of England - From the Fall of Marlborough to the Peninsular War, Vol. IV, The King's Edition Cassell and Company Limited, London, New York, Toronto and Melbourne 1909, s. 465.

${ }^{42}$ Carrington; Jackson, age, s. 575-573; Nelson against..., s. 13.

${ }^{43}$ Hughes, age, Vol. VI, s. 350; Cassell's History..., Vol. IV, s. 465.

${ }^{44}$ Hem İngiliz Denizcilik Bakanlığ 1 , hem de St. Vincent, böylesine önemli bir görev için Nelson'un en uygun kişi olduğu konusunda tereddüt yaşamadılar. Barker, age, s. 184.

${ }^{45}$ Hughes, age, Vol. VI, s. 350; Southey, age, s. 106; John Keegan, Intelligence In War - Knowledge of the Enemy from Napoleon to Al-Qaeda, Pimlico, 2004, s. 41. Kaptan Hardy'nin kumandasındaki Mutine adlı brik ise 5 Haziran'da Nelson'un filosuna katıld1. Clarke; McArthur, age, s. 460.

${ }^{46}$ Crowe, age, Vol. V, s. 47.

${ }^{47}$ Carrington; Jackson, age, s. 572.

${ }^{48}$ Napolyon, Hindistan ile ilgili planlarını hayata geçirme konusunda, Fransa'nın güçlü bir müttefiki olan ve İngiliz Doğu Hindistan Şirketi'nin de düşmanı bulunan Maisur Sultanı Tipu Sahib’e güveniyordu. Carrington; Jackson, age, s. 573.

${ }^{49}$ Green, age, Vol. IV, s. 336.

${ }^{50}$ Crowe, age, Vol. V, s. 47.

${ }^{51}$ Grimshaw, age, s. 253. 
birkaç atış, belki topraklarını değil ama sadece onurlarını korudu. ${ }^{52}$ Ada, Paris’ten gelen emir yazısına uygun bir şekilde Fransa'ya bağlandı. Ancak Fransa ile İngiltere'nin deniz gücü mukayese edildiği zaman, bu istila, sanki İngiltere adına yapılmış gibiydi. ${ }^{53}$ General Vaubois, 3 bin kişilik bir garnizonla Valletta'da kaldı. Fransız Donanması ise tekrar yola koyuldu ve Akdeniz'i taramaya başlayan Nelson kumandasındaki İngiliz Donanması'na yakalanmadan Mısır'a ulaşmayı başardı. 1 Temmuz'da Mısır kıyıları göründü, ancak İskenderiye'nin işgali ertesi günü buldu. ${ }^{54}$

Nelson'un amacı, mümkün olursa, Fransızların önünü Akdeniz'de kesmekti. Ancak elinde Fransız Donanması'nın hedefi hakkında herhangi bir bilgi yoktu. ${ }^{55}$ Tek bildiği şey, 18 Mayıs'ta yaşanan büyük firtınadan sonra Napolyon'un Toulon'dan ayrılmış olduğuydu. Bununla beraber doğru bir önsezi ile Napolyon'un hedefinin Portekiz ya da İrlanda olabileceğiyle ilgili ihtimalleri eledi. O'na göre, Sicilya/Napoli, İstanbul veya Misır Napolyon'un hedefi olabilecek üç yerdi. ${ }^{56}$ Öncelikle rotasını İtalyan sahillerine doğru çeviren Nelson, Haziran'ın 17'sinde Napoli'de demirledi. Zira düşmanın saldırabileceğini düşündüğü ilk hedef burasıydı. ${ }^{57}$ Ancak bir süre sonra Fransız Donanması'nın Malta yönünde hareket ettiğini öğrendi. 22 Haziran'da ise, Güney Sicilya'ya gelen bir yük gemisinden, Fransızların Malta'yı St. John şövalyelerinden aldıkları ve Haziran'1n 16'sında da bilinmeyen bir hedefe doğru tekrar denize açıldıkları bilgisini elde etti. Bunun üzerine Fransızların muhtemel hedeflerinin Mısır olabileceğini düşündü. ${ }^{58}$ Zira burası, Akdeniz'in ortasında oldukça stratejik öneme sahip bir yerdi. ${ }^{59}$ Vakit kaybetmek istemeyen Nelson, İskenderiye'ye doğru olabildiği kadar hızlı bir şekilde yol aldı. Ancak Nelson'un bilmediği birşey vardı. O da; daha önce öğrendiği bilgide kritik bir yanlışlığın olduğuydu. Fransızlar, Malta'dan ayın 16'sında değil, 19 'unda hareket etmişlerdi. ${ }^{60}$ Nitekim İngiliz Donanması, askerlerle dolu nakliye gemileri nedeniyle yavaş ilerleyen Fransız Donanması'nı fark etmeden geçerek İskenderiye'ye ulaştı. ${ }^{61}$ Nelson, 28 Haziran'da İskenderiye'ye göz attığında liman boştu ${ }^{62}$ ve Fransızlardan da herhangi bir haber yoktu. Düşmanın maksadı konusunda yanıldığını düşünen Nelson, ayın 30'unda tekrar yola çıkt. ${ }^{63}$ Ertesi gün, İngilizlere göre daha kuzeyden ve çok daha yavaş ilerleyen Fransız Donanması İskenderiye'ye demirledi ve karaya asker çıkarmak için hazırlandı. ${ }^{64}$ İngilizler, Fransızların İskenderiye'ye varmalarını 24 saat 1skalamışlardı. İngiliz Konsolosu George Baldwin, o sırada İskenderiye'de bulunmuyordu. Eğer olsayd1, belki Nelson bir süre

\footnotetext{
${ }^{52}$ Hughes, age, Vol. VI, s. 349. Fransızlar tarafindan esir alınan Malta Şovalyeleri gemilerle İspanya ve Portekiz'e gönderildiler. Bkz. The London Chronicle, August 9, 1798.

${ }_{53}$ Crowe, age, Vol. V, s. 47. Nitekim Malta, 1800 Eylülü’nde İngilizlerin eline geçti. Emsley, age, s. 57.

${ }^{54}$ Jervis, age, s. 588.

${ }^{55}$ Bright, age, Period III, s. 1220.

${ }^{56}$ Keegan, age, s. 68-69.

${ }^{57}$ Hunt, age, s. 416.

${ }^{58}$ Alfred Thayer Mahan, The Influence of Sea Power upon the French Revolution and Empire 1793-1812, Vol. I, Sampson Low, Marston \& Company, London 1892, s. 259; N. A. M. Rodger, The Command of the Ocean: A Naval History of Britain 1649-1815, W. W. Norton Company, New York London, 2005, s. 475.

${ }^{59}$ Keegan, age, s. 72.

${ }^{60}$ Mahan, The Life of ..., Vol. I, s. 331-332; Rodger, age, s. 475.

${ }^{61}$ Roger Knight, Britain Against Napoleon: The Organization of Victory, 1793-1815, Penguin Books, London 2013, s. 147. Aynı yöne doğru paralel bir şekilde yol alan iki donanma arasındaki mesafe ayın 25 'inde 60 mile kadar indi. Mahan, The Influence of ..., Vol. I, s. 260.

${ }^{62}$ Spencer C. Tucker, Battles that Changed History: An Encyclopedia of World Conflict, ABC-CLIO, Santa Barbara, Denver, Oxford 2011, s. 272.

${ }^{63}$ Roy Adkins, Lesley Adkins, The War for all the Oceans: From Nelson at the Nile to Napoleon at Waterloo, Penguin Books, London 2008, s. 15

${ }^{64}$ Rodger, age, s. 476.
} 
daha burada oyalanabilir ve bu şekilde Fransızlarla karşılaşabilirdi. ${ }^{65}$

Fransızlardan bir iz bulabilmek amacıyla Doğu Akdeniz'i taramaya başlayan Nelson, yaklaşık üç haftalık bir arayıșın ${ }^{66}$ ardından su ve yiyecek ihtiyaçlarını karşılamak için 19 Temmuz'da Sicilya'ya döndü. ${ }^{67}$ Ancak burada herhangi bir yeni bilgi elde edemedi. 24'ünde tekrar hareket eden ve Fransızların Doğu Akdeniz'de bir yerde olduğundan emin olan Nelson, Ege'de dolaşmaya başladı. ${ }^{68}$ Mora sahilleri boyunca gezindi. Bu arayış toplamda bir buçuk ay kadar devam etti. Keşif için kullanabileceği firkateynlerin yeterli sayıda olmamasının Nelson'un işini zorlaştırdığına şüphe yoktu. ${ }^{69}$ Düşmanın izine bir türlü ulaşamamış olmasının meydana getirdiği endişeyle giderek sabrı da tükeniyordu. ${ }^{70}$ Ancak yine de düşmanı arayıp bulma konusunda kararlı tutumundan vazgeçmedi.

\section{Napolyon'un Mısır'ı İşgali}

Misır $^{71}$, Fransa ile barış içerisinde bulunan Osmanlı Devleti'nin bir eyaleti durumundaydı. Ancak bu durum Napolyon'un tasarısı önünde bir engel olarak görülmemişti. ${ }^{72}$ Fransızlar, şiddetli bir taarruzla 1 Temmuz'da ${ }^{73}$ İskenderiye'ye asker çıkarmaya başladılar. 2 Temmuz'da İskenderiye'yi kontrolü altına alan ${ }^{74}$ Napolyon'un hedefinde Kahire vardı. ${ }^{75}$

Mısır'ın merkezi Kahire, hükümete nezaret etmesi için Osmanlı Devleti tarafından görevlendirilen bir vali tarafından idare ediliyordu. Bölgede hâkim olan unsur ise üstün atlilara sahip, savaş̧̧ılıklarıyla ünlü Memluk aileleriydi. ${ }^{76}$ Aslında Memluklular, Osmanlı Sultanı'nı ya da O'nun temsilcilerini pek de göz önünde bulundurmadan ülkeyi yönetir hale gelmişlerdi. ${ }^{77}$ 12 ila 13 bin kadar silahlı Memluklu, sadece kendi reis ya da beylerine itaat ediyordu. Bunlar arasında en güçlü olanları ise İbrahim Bey ile askerî işleri idare eden Murat Bey’di. Mısır

${ }^{65}$ Knight, age, s. 147.

${ }^{66}$ Paul Strathern, Napoleon in Egypt, Random House Publishing Group, London 2008, s. 152.

${ }^{67}$ Gregory Fremont-Barnes, Nile 1798: Nelson's First Great Victory, Illustrated by H. Gerrard, Osprey Publishing, Oxford 2011, s. 12.

${ }^{68}$ Rodger, age, s. 476.

${ }^{69}$ Hunt, age, s. 416.

${ }^{70}$ Sir William Hamilton'a gönderdiği 20 Temmuz 1798 tarihli mektupta, Nelson'un Fransız Donanması'nı bulamamasından dolayı duyduğu kaygı açıkça görülmektedir. Bkz. UK (United Kingdom), TNA (The National Archives), FO (Foreign Office) 70/11 folios 188-9.

${ }^{71}$ Fransızların hedefindeki bu ülkenin coğrafi yapısına bakmak faydalı olacaktır. Avsan şehrinden Kahire'ye kadar Nil'in her iki tarafında uzanan sıradağların böldüğü Mısır, yukarı ve aşağı olmak üzere ikiye ayrılır. Bu dağların her iki tarafı da çöllerle kaplıdır. Bunların arasında ise en geniş yeri 50 kilometreyi geçmeyen uzun bir ova yer alır. Aşağı Mısır, Kahire ile Akdeniz arasındaki tüm ülkeyi kapsar. Buna çöllerle çevrili Süveyş bölgesi de dâhildir. Nil Nehri'nin meydana getirdiği delta ise oldukça verimli topraklardan oluşur. Konumuz olan dönemde, bu topraklarda en başta pirinç olmak üzere her çeşit hububat bolca yetiştirilmekteydi. Daha eski zamanlarda Roma'nın tahıl ambarı vazifesini gören bu coğrafya, bu dönemde Osmanlı Devleti'nin bazı temel ihtiyaçlarını karşılamaktaydı. Nil'in bereketiyle sulanan topraklar hiçbir zaman nadasa bırakılmazdı. Hatta yılda üç defa mahsul alınabildiği olurdu. Baines, age, Vol. I, s. 202.

72 Napolyon'a göre, Osmanlı Sultanı'nın Avrupa'da Fransa'dan başka bir müttefiki yoktu. Guizot; Witt, age, Vol. VI, s. 386.

${ }^{73}$ Emsley, age, s. 57.

${ }^{74}$ Hunt, age, s. 416.

${ }^{75}$ Grimshaw, age, s. 253.

${ }^{76}$ Jervis, age, s. 588. Memluklular, Mısır'ın asıl askeri gücünü teşkil etmekteydiler. Bunların kullandıkları ana silah $76 \mathrm{~cm}$ uzunluğunda süvari tüfeğinden ibaretti. Ancak bu silah geniş kalibresi sayesinde bir defada on-on iki mermi ateş edebilme kapasitesine sahipti. Bu silahlar atlara monte edilmiş şekilde kullanılıyordu. Bu insanların en büyük problemleri ise, Batı'da ilerlemiş durumda olan bilimsel savaş sanatı hakkında oldukça yetersiz bilgiye sahip olmaları, topçuluktaki kifayetsizlikleri ve askeri disiplinden yoksun bulunmalarıydı. Baines, age, Vol. I, s. 203.

${ }^{77}$ XVIII. yüzyılın son çeyreğine gelindiğinde Osmanlı'nın Mısır'daki egemenliği gerçekten de oldukça zayıflamıştı. Özge Özkoç, Imparatorluk İktidarının Sinırında Osmanlı Mısırı: Mehmet Ali Paşa Döneminden Hıdivliğe, Doktora Tezi, Ankara Üniversitesi Sosyal Bilimler Enstitüsü Uluslararası İlişkiler Anabilim Dalı, Ankara 2013, s. 35. 
nüfusunun $^{78}$ önemli bir bölümünü oluşturan ve büyük oranda ticaretle uğraşan Kıptiler ${ }^{79}$, Memluklulara itaat ediyorlardı. Halkın diğer önemli bir kısmını oluşturan Araplar ${ }^{80}$ da, çok memnun olmasalar bile, yine Memluklulara boyun eğiyorlard1. ${ }^{81}$

Mısır'a geldiği zaman Memluklularla Araplar arasındaki husumeti fark etmekte gecikmeyen Napolyon, Arap şeyhlerine kendisini, Memlukluların istibdadına son verecek kişi olarak takdim etti. Nitekim özellikle Araplara yönelik olarak kaleme aldığı bildirisinde hedef tahtasına Memlukluları koydu: "Misır halkı! Size, dininizi yok etmek için geldiğimi söyleyecekler; onlara inanmayın. Onlara, haklarınızı iade etmek, zorla iktidarl ele geçirenleri cezalandırmak için geldiğimi söyleyin. Ben, Memluklulardan daha fazla Tanrı'ya, O'nun Peygamberi'ne ve Kuran'a saygı duyuyorum. Müslümanlara karşı savaş yapmanın zorunlu olduğunu söyleyen Papa'yı etkisiz hale getiren biz değil miydik? Müslümanlara karşı savaş yapmalarını Tanrı'nın emrettiğine inanmaları sebebiyle akılsız Malta Şövalyeleri'ni mahveden biz değil miydik?" 82

Bu şartlar altında Napolyon'a karşı ilk aşamada cesurca direnç gösterenlerin Memluklular olması şaşırtıcı olmadı. Aşiret reislerinden Murat Bey, Kahire'yi savunmak üzere askerlerini topladı. İskenderiye'ye hâkim olan Napolyon ise, çok vakit kaybetmeden Kahire'ye doğru harekete geçti. Kavurucu güneşin altında çölü aştı ve 21 Temmuz'da Kahire'ye vardı. Kendisini 6 bin atlı ve 20 bin piyadeden oluşan Memluklu kuvvetleri bekliyordu. Burada yapılan "Piramitler Muharebesi"ni kaybeden Memluklu ordusu Yukarı Misır'a ve oradan Suriye tarafına doğru çekilmek zorunda kaldı. ${ }^{83}$

24 Temmuz'da Kahire'yi kontrolü altına $\operatorname{alan}^{84}$ Napolyon, vakit geçirmeden ülkeyi kendisine göre teşkilatlandırmaya başladı. Halkın gönlünü kazanmak için ise, kendisinin de

\footnotetext{
${ }_{78}^{78}$ Misır'in nüfusu toplamda 4 milyonu buluyordu. Baines, age, Vol. I, s. 203.

${ }^{79}$ Kıptiler, Mısır'ın yerli halkıyd. Bunlar Hıristiyanlığın bir koluna inanıyorlardı. Ayrıca İstanbul'da kendilerini temsil eden bir de patrikleri mevcuttu. Genel olarak iç ticaretle uğraşıyorlardı. Özellikle Mısır sakinlerinin uzun süredir uğraştıkları arıcılık ve civciv üretim ve ticaretiyle meşguldüler. Baines, age, Vol. I, s. 202-203.

${ }^{80}$ Mısır halkının üçte ikisini oluşturan Arapları üçe ayırabiliriz. Nil kıyılarında yaşayan Araplar, genelde yağmacılık ve korsanlık yapıyorlardı. Yukarı Mısır'dakiler ise çeşitli beyliklere sahiptiler. Şeyhleri tarafından yönetilen bu Araplar, eli açık ve kimliklerini gizleme konusunda başarılı olamayan insanlardı. Üçüncü grubu oluşturan bedeviler ise, sürekli olarak ülkede geziniyorlardı. Konargöçer hayat yaşayan bu insanların sürekli bir ikametgâhları yoktu. Baines, age, Vol. I, s. 203.

${ }^{81}$ Guizot; Witt, age, Vol. VI, s. 383-384.

${ }^{82}$ Age, s. 384. Napolyon'un bu iddialarına verilen güzel cevaplardan birisi dönemin İngiliz Başbakanı Genç William Pitt'ten geldi. İngiltere Parlamentosu'nda yaptığı bir konuşmada Pitt, Napolyon'un Mısır Seferi ve niyetleri hakkında şu değerlendirmelerde bulundu: “... (Bu) saldırı, öldürdükleri Fransız Kralı adına yapıldl. Topraklarına tecavüz ettikleri Padişah'ın onayını almış gibi davranıyorlardı... Fransa'nın Müslümanlık inancıyla barıştığı ilan edildi... Dost ve tarafsız toprakları vahşice istila etmesindeki gizlemeye çalıştı̆̆ tek amaç, Hindistan'daki İngiliz hâkimiyetine giden yola saldırmaktı. Mısır'a yapılan saldırıya, Hindistan'daki İngiliz servetine karşı devrimci ilkelere dayalı olarak yapılan saldırı eşlik etti... (Mısır'daki) haleflerine, Türklerle olan tüm müzakerelerinde, düşmanca planlarla ve ülkeyi ele geçirme niyetiyle Misır'a gelmediği üzerinde güçlü, sürekli ve ısrarlı bir şsekilde durmalarını emretti. Hâlbuki aynı talimatın arka sayfasında, en gözde projesi olan Misır' i ilhak etme ve sömürgeleştirmede yaşadiğı hezimetten duyduğu üzüntü hiç şüpheye yer birakmayacak şekilde yer almaktaydı." The Speeches of the Right Honourable William Pitt, in the House of Commons, Vol. III, The Third Edition, Printed for Longman, Hurst, Rees, Orme, and Brown, London 1817, s. 116-117, 131-132. Annals of the Life of the Right Honourable William Pitt, Printed by B. Graves-Sold by H. Maxwell, Philadelphia 1806, s. 105, 106; Life of William Pitt, Late Prime Minister of Great Britain: With Biographical Notices of His Principal Friends and Illustrious Contemporaries, John Watts, Philadelphia 1806, s. 181-182.

${ }^{83}$ Jervis, age, s. 588. Bu savaşta Memluklular 2 bin adam kaybettiler. Napolyon'un kaybı ise oldukça azdı. Hazen, age, s. 255. Her ne kadar Memluklular yetenekli savaşçılar olsalar da, Fransız askerlerinin silah üstünlüğüyle rekabet edebilecek düzeyde değildiler. Neely, age, s. 242.

${ }^{84}$ Emsley, age, s. 57.
} 
Hz. Muhammed'e inandığı imasında bulundu. ${ }^{85}$ Yine de Fransız askerlerindeki ateizm ve bencilce hareketler, bölge halkını ve Türkleri kendisine karşı öfkelendirmekten başka bir sonuç doğurmad1. ${ }^{86} \mathrm{Bu}$ olumsuzlukların yanında, Mısır'ın işgalinde elde ettiği başarıya ve hayallerine büyük darbe indirecek olan bir gelişmeyle de yakın bir zaman sonra yüzleşmek zorunda kaldı.

\section{Savaş Öncesi Taraflar}

Fransızların Mısır'a ayak basmalarının üzerinden neredeyse 1 ay geçmişti. Tüm bu süre zarfında Nelson, Fransızlardan bir iz bulabilmek ümidiyle Akdeniz'de dolanıp durdu. Nihayet Temmuz'un 28'inde, Fransızların 4 hafta kadar önce Mısır yönünde yol aldıklarına dair bir bilgi aldı ${ }^{87} \mathrm{Bu}$ haber doğrultusunda hemen harekete geçen Nelson, Ağustos'un ilk günü öğle vakti İskenderiye'ye yaklaştı. Limanın Fransız nakliye gemileriyle dolu olduğunu gördü ancak savaş gemileri ortada yoktu. ${ }^{88}$ Fransız Donanması'nın burada olmadığını gören İngiliz mürettebat iyiden iyiye umutsuzluğa kapıld $1{ }^{89}$ Bununla beraber İskenderiye dışında Misır sahillerinde Fransız savaş gemilerinin demirleyebilecekleri bir yer daha vardı. O da 15 mil kadar kuzeydoğuda yer alan Ebukır Koyu'ydu. ${ }^{90}$

Fransız savaş gemilerinin Ebukır'da olduğunu ilk keşfeden Zealous adlı savaş gemisinin kaptanı Hood oldu. ${ }^{91}$ Nelson ise ikindi vakti Ebukır Koyu'na ulaştı ve Fransız Donanması'nın burada tek bir hat üzerinde demirli olduğunu gördü. ${ }^{92}$ Fransızlar, İskenderiye'ye çıkarma yapmışlardı ancak büyük savaş gemileri sı̆̆ olan limana girememişti. ${ }^{93}$ Üstelik burası, düşman tarafından ablukaya alınmaya da oldukça müsait görünüyordu. ${ }^{94}$ Ebukır Koyu ise büyük gemiler için daha uygundu. Buradan Fransız ordusunun ardını korumak da mümkün olabilirdi. $\mathrm{Bu}$ nedenlerle Koramiral Brueys, donanmasını 8 Temmuz'da Reşit Şehri'ndeki bu koya demirlemişti. ${ }^{95}$

Fransız Donanması, güçlü ve sık bir hat üzerinde sıralanmıştı. Gemilerin yan tarafları sahile bakıyordu. En baştaki gemi, kuzeybatı yönünde ve sı̆̆ kumsala yakın bir konumda bulunuyordu. Donanmanın geri kalan kısmı ise, daha derin olan bir hat boyunca bir tür eğri oluşturmuştu. Toplamda 13 savaş gemisi ve 4 fırkateyn vardı. Brueys, donanmasını, üç güvertesinde toplam 120 topa sahip Orient adlı savaş gemisinden idare ediyordu. Kaptanlığını Casa Bianca'nın yaptığı bu dev geminin 1010 kişilik mevcudu vardı. Kaptanlığını Tuğamiral Armand Blanquet du Chayla'ın yaptığı Franklin, Tuğamiral Pierre Charles Comte de Villeneuve'ün kumandasındaki Guillaume Tell ile Tonnant adlı savaş gemileri ise, 80 top ve 800 kişilik mürettebatlarıyla Orient'dan sonra Fransız Donanması'nda yer alan en büyük savaş

\footnotetext{
${ }^{85}$ Napolyon, "Biz gerçek Müslümanlarız." savına Müslümanları inandırmak için her şeyi yaptı. Her yerde İslam adına savaştığını kanıtlamaya çalıştı. Söylediği her söz Kuran Arapçası'na çevrildi. Kendisini Mısırlılara zorla benimsetmek için gücünün yetersiz kaldığını görür gibi olduğunda, yerel imamlara, kadılara, müftülere, ulemaya, Kuran'1, Fransız Ordusu lehinde tefsir ettirmeye çalıştı. Said, age, 91-92.

${ }^{86}$ Bright, age, Period III, s. 1220.

${ }^{87}$ Barker, age, s. 194.

${ }^{88}$ Mahan, The Influence of..., Vol. I, s. 261; Rodger, age, s. 476.

${ }^{89}$ Roger Knight, The Pursuit of Victory: The Life and Achievement of Horatio Nelson, Basic Books, New York 2005, s. XXXII.

${ }_{90}$ Oliver Warner, Nelson's Battles: The Triumph of British Seapower, Pen and Sword Military Classics, S. Yorkshire 2003, s. 47.

${ }^{91}$ Barker, age, s. 197; Mahan, The Life of ..., Vol. I, s. 343.

92 Thompson, age, s. 303. İngiliz Amiral, Fransızları bulamama kaygısından dolayı uzun bir süredir uyuyamıordu. Sonunda uzun aramaları neticesini verdi. Thoyras, age, Vol. II, s. 612.

${ }^{93}$ Guizot; Witt, age, Vol. VI, s. 386.

${ }^{94}$ William James, The Naval History Of Great Britain, From the Declaration of War by France in 1793, to the Accession of George IV, Vol. II, Richard Bentley, London 1837, s. 157.

${ }^{95}$ Mahan, The Life of..., Vol. I, s. 345; Hunt, age, s. 416.
} 
gemileriydi. 700 kişilik 74 topa sahip olanlar ise, Guerrier, Conquerant, Spartiate, Aquilon, Peuple Souverain, Heureux, Timoleon, Mercure ve Genereux idi. Frrkateynlerden Diane 48 topa, Lustice ise 44 topa sahipti. Her ikisinin de 300'er mevcudu vard1. Artemise ve Serieuse adlı firkateynlerin ise 36 topu ve 250 'şer mürettebatı mevcuttu. Bunlardan başka 18 topa sahip Alert, Infanta ve Castor adlı havan gemileri de bulunmaktayd $1 .{ }^{96}$

Nelson'un donanmasında da yine 13 savaş gemisi bulunuyordu. Ancak 74 topa ${ }^{97}$ sahip bu gemilerden hiçbirisi, 120'lik Orient ile boy ölçüş̧ebilecek büyüklükte değildi. Ayrıca 1 adet firkateyn ve 1 adet de brik $^{98}$ vardı. Savaş gemilerinden Vanguard, İngiliz Donanması'na komuta eden Nelson'un bulunduğu amiral gemisiydi. Kaptan Edward Berry'nin ${ }^{99}$ idaresindeki bu savaş gemisi 74 topa ve 595 kişilik mürettebata sahipti. ${ }^{100}$ Geminin aşağ 1 güvertedeki uzunluğu 51 metreyi (168 fit) buluyordu. 1.600 ton taşıma kapasitesine sahipti. Gemiyi dengelemek için kullanılan ağırlıkların miktarı 349 tondu. Ekipmanların ve ambardaki malların ağırlığı ise 971 ton geliyordu. Bu ağırlığa, ağır toplar da dâhildi. 32 kalibreliklerin arabalarının ağırlığı 3 tondan, 18 kalibrelik olanların ağırlığ 1 ise 2 tondan fazlaydı. Tüm silahların toplam ağırlığı ise 187 ton geliyordu. Mürettebatın ve onlara ait eşya ve yatak takımlarının ağırlığı da 45 ton kadardı. Demirlemek için kullandığı halatın ${ }^{101}$ ağırlığı bile 20 tonu geçiyordu. $\mathrm{Bu}$ miktardaki bir ağırlık elbette tahtadan yapılma bir gemi için oldukça fazlaydı. ${ }^{102}$

Yukarıda bahsettiğimiz gibi St. Vincent, Bonapart'ın peşine düşen Nelson'un küçük filosunu takviye etmek için en iyi 10 savaş gemisini, bir adet firkateyn ve bir adet de brikle beraber göndermişti. Bunlardan Kaptan Thomas Louis'in emrindeki 74 toplu Minotaur adlı savaş gemisinin 640 personeli vardı. Kaptan Thomas Troubridge'in emrindeki Culloden, Kaptan R. W. Miller'ın kumandasindaki Theseus, Kaptan B. Hallowell'in idaresindeki Swiftsure, Kaptan Davidge Gould'un kumanda ettiği Audacious, John Peyton'ın kaptanlığını yaptığı Defence, Kaptan Samuel Hood'un komuta ettiği Zealous, Kaptan Thomas Foley'in

\footnotetext{
${ }^{96}$ UK, TNA, DO (Dominions Office), Maps and Plans, MPI 1/536 Number 6; UK, Somerset Heritage Centre (South West Heritage Trust), DDISAS\C/795/SX/45; UK, Shropshire Archives, 146/27; The London Gazette Extraordinary, Published by Authority, October 2, 1798 (1665 yllında yayınlanmaya başlayan bu gazete, İngiltere'nin resmi yayın organıdır. Üç neşriyattan oluşmaktadır: The London Gazette, salı ve cuma günleri yayınlanan The Edinburgh Advertiser ve sadece cuma günleri yayılanan The Belfast Gazette. Bkz. https://www.thegazette.co.uk/about); The Times, October 3, 1798; The Edinburgh Advertiser, Published by Authority, October 5, 1798; The Glasgow Advertiser, September 18, 1798. Ayrica bkz. Baines, age, Vol. I, s. 205, 206, 208; Thoyras, age, Vol. II, s. 612-613; Barker, age, s. 215; Cassell's History..., Vol. IV, s. 467.

${ }^{97}$ Fransiz deniz kuvvetleri bu dönemde çok sayıda 74'lük savaş gemisine sahipti. Bunlar iki güverteli gemilerdi. Zira Fransızlar, makul miktarda silah taşıyabilecek hızlı savaş gemilerine ihtiyaç hissediyorlardı. İngilizler de bu gemi tarzını takdir ettiler ve birçok 74'lük savaş gemisi inşa etmeye başladılar. Ancak farklı stratejik ihtiyaçlara sahip İngilizlerin 74'lükleri Fransızlarınkilerden daha kısa olarak tasarlandı. Nicholas Tracy, Nelson's Battles: The Triumph of British Seapower, Seaforth Publishing, Barnsley UK 2008, s. 54.

98 Brik, önceleri, Kuzey Avrupa'da ticaret için kullanılan oldukça gözde ve başarılı bir gemi tipiydi. Blake; Lawrence, age, s. 59.

${ }^{99}$ Kaptan Edward Berry, Nil Savaşı'ndan sonra Fransızlara esir düştü. Birkaç ay sonra şartlı olarak salıverildi ve 1798 kışında İngiltere'ye döndü. Hemen ardından ise Nil Savaşı'nda yaşananları, “An Officer of Rank in the Squadron" ismini kullanarak kitap şeklinde yayınlad1. Bkz. Edward Berry, An Authentic Narrative of the Proceedings of His Majesty's Squadron: Under the Command of Rear-Admiral Sir Horatio Nelson, from its Sailing from Gibraltar to the Conclusion of the Glorious Battle of the Nile; Drawn up from the Minutes of an Officer of Rank in the Squadron, The Second Edition, T. Cadell, Jun. and W. Davies, (Successors to Mr. Cadell), London 1798.

${ }^{100}$ UK, TNA, DO, MPI 1/536 Number 6; UK, Shropshire Archives, 146/27; The London Gazette Extraordinary, October 2, 1798; The Times, October 3, 1798; The Edinburgh Advertiser, October 5, 1798; The Glasgow Advertiser, September 18, 1798. Ayrica bkz. Baines, age, Vol. I, s. 208; Thoyras, age, Vol. II, s. 613; Barker, age, s. 214.

${ }^{101}$ İngiliz gemileri büyüklüklerine göre 4 ila 7 tane tersane yapımı demir taşıorlardı. Kullanılan halatlar ise 1793'e kadar sadece en iyi kenevirin geldiği Bridport ve Dorset’te yapiliyordu. Blake; Lawrence, age, s. 150.

${ }^{102}$ Knight, The Pursuit of ..., s. XXXII-XXXIII.
} 
emrindeki Goliath, Kaptan George B. Westcott'un kumandasındaki Majestic ve Kaptan Henry D. E. Darby'nin komutasındaki Bellerophon 74 topa sahip 590 kişilik savaş gemileriydi. Kaptan Alexander J. Ball'un komutasındaki Alexander ile Sir James Saumarez'in kaptanlığını yaptığ 1 Orion ise, başından beri Nelson'un emrinde bulunan 74 topa ve 590 mürettebata sahip diğer iki savaş gemisiydi. Kaptan T. B. Thompson'ın idaresindeki Leander adlı firkateynin 50 topu ve 343 mevcudu vardı. Mutine adlı 14 topa sahip brikin kaptanlığını ise T. M. Hardy yapiyordu. ${ }^{103}$

İki donanmayı kıyasladığımız zaman Fransızların donanmasının sayı, büyüklük ve ağırlık olarak Nelson'un donanmasından çok daha üstün olduğunu söyleyebiliriz. Aslında silah ve hatta asker sayısı itibariyle de Fransızlar, İngilizlerden üstün durumdaydılar. Zira Fransız Donanması'nda, toplamda 1.190 silah ve 10.810 askere sahip 13'ü savaş gemisi olmak üzere 17 gemi mevcuttu. İngilizlerin de savaş gemisi sayısı aynıdı. Ancak firkateyn sayısı daha azd1. Bu gemilerde ise toplamda 1.012 silah ve 8.068 asker bulunuyordu. İngiliz gemileri 74'lüklerden meydana geliyordu. Fransızların ise 3 tane 80'lik ve bir tane de üç güvertesinde toplam 120 silah bulunan büyük savaş gemileri vardı.

Tüm bu üstünlüklerine rağmen Fransızların bazı dezavantajları da söz konusuydu. Mesela Fransız gemileri aceleyle donatılmışlardı. ${ }^{104}$ Bunlara muhtelif tarzda silahlar yerleştirilmişti. Gemilerden bir tanesi, 32 kalibrelikler yerine, 18 kalibrelik toplara sahipti. ${ }^{105}$ Bir kısmının çok iyi durumda oldukları da söylenemezdi. ${ }^{106}$ Bazıları 50 yıllıktı ve İngiliz gemilerine göre daha az sağlam yapılmışlardı. ${ }^{107}$ Ayrıca kaptanları cesur ve gayretli olsalar da, mürettebatın çoğunun denizci olmaması büyük bir eksiklikti. ${ }^{108}$ İhtilal, Fransız Donanması'nı birçok iyi subaydan mahrum bırakmıştı. Var olanlar ise İngilizlere kıyasla tecrübesizdiler. ${ }^{109}$

Ancak Fransız Donanması'nın İngilizler karşısında önemli bir avantajı vardı. Bu da, koy içerisinde aldıkları savaş pozisyonuydu. Donanma, Ebukır Koyu'nun batı tarafında geniş sı̆̆ kıyının biraz açığında demirli vaziyetteydi. ${ }^{110}$ Brueys, demirli konumda savaşmanın daha avantajlı olduğunu düşünüyordu. Gemilerin arasında, eksenleri etrafinda dönebilecekleri kadar boşluklar bırakılmıștı. ${ }^{111}$ Önlerinde, tabyası da bulunan Ebukırr ${ }^{12}$ (Bequieres) Adası bulunuyordu. Kaptan gemisi Ada'nın kumsalına oldukça yakındı. ${ }^{113}$ Yan taraflarını ise gambotlar koruyordu. ${ }^{14}$ Üstelik birçok yerde bulunan kayalıklar sayesinde bir saldırı

${ }^{103}$ UK, TNA, DO, MPI 1/536 Number 6; UK, Shropshire Archives, 146/27; The London Gazette Extraordinary, October 2, 1798; The Times, October 3, 1798; The Edinburgh Advertiser, October 5, 1798; The Glasgow Advertiser, September 18, 1798. Ayrica bkz. Clarke; McArthur, age, s. 460; Baines, age, Vol. I, s. 208; Thoyras, age, Vol. II, s. 613; Barker, age, s. 214; Keegan, age, s. 41. Bu dönemdeki İngiliz Donanması hakkında geniş bilgi için bkz. Rif Winfield, British Warships in the Age of Sail 1793-1817: Design, Construction, Careers and Fates, Seaforth Publishing, South Yorkshire 2008.

${ }^{104}$ Hughes, age, Vol. VI, s. 351.

105 Keegan, age, s. 61.

${ }^{106}$ Hunt, age, s. 416.

107 1805'te yaşanan Trafalgar Savaşı'nda Nelson'un amiral gemisi 40 yaşındaydı. Ne gemilerin yaşı, ne de ağırlıkları, insanların niteliklerinin önüne geçebildi. Zira zaferin elde edilmesinde, denizcilik bilgisi ve yeteneği ile yerinde kararlar, maddi üstünlüklerden daha belirleyiciydi. Keegan, age, s. 61.

${ }^{108}$ Hunt, age, s. 416.

${ }^{109}$ Keegan, age, s. 61.

${ }^{110}$ Hunt, age, s. 416.

${ }^{111}$ Rodger, age, s. 476.

112 İngilizler, Ebukır'da kazanılan zafer sonrası bu Ada'ya Nelson Adası adını verdiler. Mahan, The Influence of..., Vol. I, s. 263; Hunt, age, s. 416.

${ }^{113}$ Hunt, age, s. 416.

${ }^{114}$ Bright, age, Period III, s. 1221. 
ihtimaline karşı endişesiz görünüyorlardı. ${ }^{115}$ Gerçekten de Fransızlar, saldırılması oldukça riskli bir şekilde pozisyon almışlardı.

Brueys'e göre bu koşullarda düşmanın sadece iki yönden yaklaşması mümkündü. İngilizler, ya Ebukır Adası'ndan aşağıya doğru yaklaşmaya çalışacaklardı ki bu yönden yapılacak bir ilerlemeyi kuzeyden esen rüzgârlar imkânsız kılıyordu ya da kıyıdaki kale ile Ada arasındaki boşluktan ilerlemeyi deneyeceklerdi. Anlaşılan o ki Brueys, Ada ile kale arasındaki boşluktan geçilebilmesini de pek mümkün görmüyordu. İngilizler geçmeyi deneseler bile bu boşluğun ilerisindeki su yeterince derin değildi. Bu durum, hem kendi gemilerinin oluşturduğu hat ile Ebukır Adası arası hem de yine Fransız hattı ile sahil arasında kalan kısım için geçerliydi. ${ }^{116} \mathrm{Bu}$ şartlarda İngilizlerin başarılı bir saldırı gerçekleştirmelerini mümkün görmeyen Brueys, belki de bu nedenle gözcülük yapmaları için küçük gemilerden yararlanma yoluna gitmedi. Nitekim Fransızlar, İngiliz Donanması'nın yaklaşmakta olduğuna dair herhangi bir uyarı alamadılar. ${ }^{117}$

1 Ağustos'ta düşman donanmasını karşısında gören Brueys, İngilizlerin aynı gün saldıracaklarına da ihtimal vermedi. ${ }^{118}$ Ancak Nelson, Fransız Donanması'nın büyüklüğüne ve oldukça ihtiyatlı hareket etmeyi gerektirecek avantajlı pozisyonuna rağmen vakit kaybetmeden savaşmaya niyetliydi. ${ }^{119}$ Napolyon'un peşine düştüğü ilk anda St. Vincent'a, "İster hareket halinde, isterse demirli vaziyette olsunlar, onlarla karşılaştı̆̆ım anda savaşacağımdan emin olabilirsiniz." diye yazmıştı. Bir başka yazısında ise, "Eğer filoları, Toulon kadar güçlü bir limanda demirli değilse, hiçbir şey onlara saldırmamı engelleyemez." diyordu. ${ }^{120}$ Nitekim aynı gün saldırı emrini vermekte tereddüt etmedi. ${ }^{121}$ Ama eskiden beri uygulana gelen düşman donanmalarının birbirlerine karşı paralel hatlar oluşturup çarpışmaları usulünü kullanmak istemedi. Fransız gemilerinin limanda aldığı pozisyonu gören Nelson, bu durumdan faydalanabileceği bir yöntem uygulamaya karar verdi. Bu plana göre İngiliz gemileri üçe ayrilacak ve bir kısmı Fransız hattı ile sahil arasına girecekti. Zaten demirli bulunan Fransız gemileri ile sahil arasına girilmesini sağlayacak miktarda su da mevcut görünüyordu. Nitekim O'na göre, düşman gemisinin hareket edebildiği bir yerde kendi gemisinin de demirleyebileceği kadar bir alan mutlaka vard. ${ }^{122}$ Geri kalan gemiler ise diğer taraftan saldıracaktı. Bu şekilde düşman donanmasının bir kısmı iki ateş arasına alınarak ezilecekti. ${ }^{123}$ $\mathrm{Bu}$ genel taktik belirlendikten sonra, Nelson, bu planı hayata geçirmeleri için oldukça güvendiği kaptanlarına ${ }^{124}$ kendi inisiyatiflerini kullanma yetkisi verdi. Her gemi en etkili olabileceği şekilde hareket edecekti. ${ }^{125}$

Nelson, Fransız Donanması'nı bulma arayışı içerisindeyken de kaptanlarını Vanguard'da

${ }^{115}$ Hunt, age, s. 416.

${ }^{116}$ Keegan, age, s. 62-63.

${ }^{117}$ Guizot; Witt, age, Vol. VI, s. 386.

${ }_{118}$ Rodger, age, s. 477.

${ }^{119}$ Grimshaw, age, s. 253.

${ }^{120}$ Mahan, The Life of..., Vol. I, s. 327.

${ }^{121}$ Green, age, Vol. IV, s. 337.

122 Thoyras, age, Vol. II, s. 612-613; Barker, age, s. 200; Keegan, age, s. 63.

${ }^{123}$ UK, West Sussex Record Office, Buckle/223. Ayrica bkz. Cassell's History..., Vol. IV, s. 467; Hughes, age Vol. VI, s. 352-353; Samuel Rawson Gardiner, A Student's History of England from the Earliest Times to 1885 , Longmans, Green, and Co., London, New York 1892, s. 838.

${ }^{124}$ Nelson'un kaptanları hakkında geniş bilgi için bkz. William Henry Fitchett, Nelson and his Captains: Sketches of Famous Seamen, Smith, Elder \& Co., London 1902.

${ }^{125}$ Hughes, age, Vol. VI, s. 353. Amiral gemisinin kaptanı Edward Berry'nin kişisel görüşüne göre, Nil'de gösterilen İngiliz başarısında, Nelson'un her bir kaptanına planı hakkında savaş öncesi yaptığı izahatın büyük rolü oldu. Berry, age, s. 17; Nelson the New Letters, Edited by Colin White, The Boydell Press, Suffolk-New York 2005 , s. 206. 
sık sık toplamış ve Fransızlarla karşılaşabilecekleri farklı şartlarda ne gibi savaş stratejileri ve taktikleri uygulayabilecekleriyle ilgili olarak görüş alışverişinde bulunmuştu. Dolayısıyla kaptanlar, kendisinin taktikleriyle ilgili olarak zaten malumat sahibiydiler. ${ }^{126}$ Uygulanacak olan yukarıdaki plan ise, Nelson'un 18 Haziran'da yaptığı ayrıntılı savaş planına dayanıyordu. $\mathrm{Bu}$ plana göre fillo üç kısma ayrılacak ve her bir kısmın komutanı emrindeki gemilerin idaresinden sorumlu olacaktı. Ayrıca Nelson, özel bir sinyalleşme yöntemiyle emrindekilerle iletişim kuracaktı. ${ }^{127}$

Fransızlara gelince, 13 savaş gemisini kıyıya oldukça yakın bir şekilde demirlemişlerdi. ${ }^{128}$ Brueys, bu şekilde sadece sancak tarafından saldırıya uğrayabileceğini düşünüyordu. ${ }^{129}$ O'na göre kıyı ile Fransız Donanması arasına girilmesi mümkün değildi. ${ }^{130}$ Nitekim Fransızlar, bu yönden bir saldırı beklemedikleri için gemilerin kıyıya bakan tarafında yeterli miktarda silah bulundurmamışlardı. ${ }^{131}$

Nelson'un planı cesaret istiyordu; ancak işe yararsa İngilizler oldukça avantajlı bir hale gelebilirlerdi. Nitekim Nelson, cesaretli ve kararlıydı. Amiral gemisinin kaptanı, "Ĕ̆ger başarılı olursak dünya bu konuda ne düşünecek?" diye sorduğu zaman Nelson, "Bu konuda 'eğer' yok! Başaracă̆ız; ama bunu söyleyecek kadar yaşayacak mıyız, bu başka bir mesele." cevabın 1 verdi. ${ }^{132}$

\section{Nil Savaşı}

Oldukça geniş bir eğri şeklindeki Ebukır Koyu, Nil Nehri'nin ağzına oldukça yakın bir yerde bulunuyordu. Bu nedenle bu koyda yapılan savaşa Nil Savaşı adı verildi. ${ }^{133}$ Savaşın başlaması ise şu şekilde oldu: Fransız Donanması'nı Ebukır Koyu'nda demirli vaziyette gören Nelson'un vakit kaybetmeden saldırmaya karar verdiğini söylemiştik. Aslında bu saatte Ebukır Koyu'na girmek bir riskti. ${ }^{134}$ Ancak Nelson, Akdeniz rüzgârları ve kara esintileriyle ilgili tecrübeliydi ve rüzgârın genelde kıyıya paralel olarak estiğini biliyordu. Üstelik Ebukır Koyu'nu da tanıyordu. ${ }^{135}$ Nitekim Fransız Donanması'nı bulduğu günün akşamına doğru saat 17.30 'da bir muharebe hattı oluşturdu. ${ }^{136}$ Ancak bu ana hatta, Kaptan Thomas Troubridge ile Kaptan Thompson'ın komutasında bulunan Culloden ve Leander adlı gemiler yer almadi. ${ }^{137}$ Nelson, kaptanlarına saldırı planını açıkladıktan sonra, "Zafer kazanacağız ve sonra bundan mümkün olduğu kadar iyi bir şekilde yararlanacă̆ız." dedi. ${ }^{138}$ Rüzgâr Fransız Donanması'na doğru esmeye başlayınca da, kararan havada savaşmanın risklerini kabullenerek harekete geçmeye karar verdi. ${ }^{139}$ Savaş başladığı zaman saat 18.30 'u biraz geçiyordu. ${ }^{140}$

\footnotetext{
${ }^{126}$ Berry, age, s. 17-18; Barker, age, s. 195; Hughes, age, Vol. VI, s. 352; Southey, age, s. 112.

127 Berry, age, s. 18-19; Nelson the..., s. 206. Kraliyet Donanmas1, Amiral Lord Howe tarafindan 1790 y1linda tasarlanan şifreli bir işaretleşme yöntemi kullanıyordu. Blake; Lawrence, age, s. 152.

${ }^{128}$ Southey, age, s. 111.

${ }^{129}$ Carrington; Jackson, age, s. 573.

${ }^{130}$ Guizot; Witt, age, Vol. VI, s. 386.

${ }^{131}$ George Alfred Henty, At Aboukir and Acre: A Story of Napoleon's Invasion of Egypt, Charles Scribner's Sons, New York 1898, s. 71; Carrington; Jackson ${ }_{2}$ age, s. 573.

132 Barker, age, s. 198; Guizot; Witt, age, Vol. VI, s. 386; Southey, age, s. 113.

133 J. Christopher Herold, Bonaparte in Egypt, Harper \& Row, New York 1962, s. 102; Bright, age, Period III, s. 1220-1221; Thompson, age, s. 303.

${ }^{134}$ Mahan, The Life of..., Vol. I, s. 343. Bu riski gönüllü olarak alan Koramiral'in 40. doğum gününe iki ay kalmıştı. Knight, The Pursuit of ..., s. XXXIII.

${ }^{135}$ Knight, The Pursuit of ..., s. XXXI-XXXII.

${ }^{136}$ Mahan, The Life of..., Vol. I, s. 348.

${ }^{137}$ Hunt, age, s. 416-417.

138 Thoyras, age, Vol. II, s. 612.

${ }^{139}$ Hunt, age, s. 416; Rodger, age, s. 477.
} 
Öncelikle İngiliz Donanması'nın öncü gemileri düşman hattının ileri ucuna doğru yelken açtı. ${ }^{141}$ Oldukça küçük olan Ebukır Adası'na yaklaşmaya başladıklarında, Fransız havan gemilerinden Alert, Brueys'in emri doğrultusunda, İngiliz gemilerine karşı durmak üzere harekete geçti ve atış mesafesine kadar yaklaştı. Ardından manevra yaparak onları Ada'nın sığ tarafına doğru çekmeye çalıștı. ${ }^{142}$ Zira Fransızlar, Ebukır Adası'na iki adet havan topu yerleştirmişlerdi. ${ }^{143}$ Ancak İngiliz Amiral bu tuzağa düşmedi. Aradaki mesafe nedeniyle bu toplar İngiliz gemilerine karşı önemli bir fayda sağlayamadı. ${ }^{144}$ Üstelik İngilizler, bu 13 inçlik toplardan birisini tahrip etmeyi başardılar. ${ }^{145}$ Nelson'un filosu ilerlemesini sürdürünce, bu sefer Fransızlar, hat boyunca yer alan tüm gemilerin sancak tarafından İngiliz gemilerinin pruva tarafına doğru kesintisiz ateşe başladılar. ${ }^{146}$

Bu arada Thomas Foley'in kaptanlığını yaptığı öncü gemisi Goliath'ın liderliğindeki bazı İngiliz gemileri, Fransız Donanması'nın oluşturduğu hattın ileri kolunun bulunduğu güneybatı yönüne doğru harekete geçti. Önde gelen Fransız gemilerinden 74 topluk Guerrier, hattın başında kıyıya yakın bir konumda yer alıyordu. ${ }^{147}$ Nitekim kıyı ile Fransız gemileri arasına girmek için en uygun yer burası gibi görünüyordu. Bu başarılabilirse İngilizler çok önemli bir taktiksel üstünlük elde etmiş olacaklardı. Zira Fransız gemilerinin sahile bakan taraflarındaki silahların başında yeterince asker yoktu ve hatta bu silahlar belki ateş etmeye bile hazır değildi. Ancak bu planı hayata geçirmek için hızlı bir şekilde hareket etmek, Guerrier'i geçmek ve bunun için de Fransızları yıkıcı bir ateş yağmuruna tutmak gerekiyordu. ${ }^{148}$

İngilizlerin elinde Ebukır sahiline ait detaylı sadece iki harita mevcuttu. Bunlardan birisi, hatta daha iyi olanı, Kaptan Foley'de bulunuyordu. Üstelik bu harita, kıyı çizgisine kadar olan alanda suyun nerede ne kadar derin olduğunu da gösteriyordu. ${ }^{149} \mathrm{Bu}$ haritadan verimli bir şekilde faydalanmasını bilen Foley, Fransız hattının baş tarafına yaklaştığı zaman uygun firsatı yakaladığını düşündü ve hızlı bir kararla sahil tarafına geçilmesi için mürettebatına emir verdi. Nitekim kaptanlığını yaptığı Goliath, Guerrier'in önünden geçerek Nelson'un planına uygun bir şekilde sahil ile Fransız Donanması arasındaki çok da sı̆̆ olmayan bölüme girmeyi başaran ilk gemi oldu. Guerrier'in arkasında yer alan Fransız gemilerinden Conquerant da kıyıa yakın bir pozisyonda bulunuyordu. Nitekim Goliath, onun yanına gelerek ateş açmaya başladı. Zealous adlı İngiliz gemisinin Kaptanı Hood da, Foley gibi Guerrier'in önünden geçip kıyı tarafından yanına yaklaştı ve ateşe başladı. Onu, Orion, Theseus ve Audacious adlı üç İngiliz gemisi daha takip etti. Bunlar, Guerrier'in yanından geçerken saldırıya başladı ve yanaştıkları Conquerant, Spartiate, Aquilon ve Peuple Souverain adlı Fransız gemilerini bombardımana tuttu. Bu şekilde 5 İngiliz gemisi, sahil ile düşman donanması arasına girip Fransızların tahmin edemedikleri şekilde saldırıya geçmiş oldu. Nelson'un gemisi Vanguard ve yanında bulunan Minotaur ise dış taraftan hücuma geçti. İngiliz Donanması'nın yarısından fazlası, Fransız hattının ileri kolunu oluşturan 5 Fransız gemisini bombalamaya başladı ve bu suretle Fransız

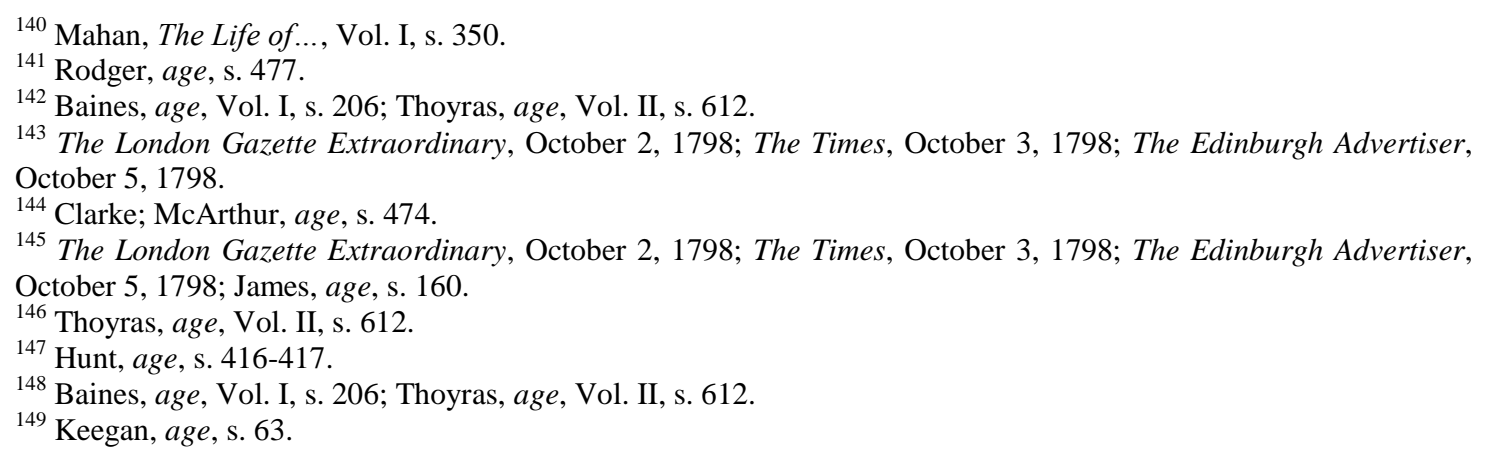


gemileri iki ateş arasında kalmış oldu. ${ }^{150}$ Böylece İngilizler, Fransız gemilerinin doğrudan doğruya borda tarafına ateş etme imkânını da yakalamış oldular. ${ }^{151}$ Brueys, zayıf savaş gemilerini, doğrudan saldırının kolay olmayacağını düşündüğü Fransız hattının baş tarafına yerleştirmişti. Ancak bu düşüncenin aksine, hattın ucundaki gemiler çok kuvvetli bir saldırıya maruz kaldığı gibi, diğer Fransız savaş gemileri de onlara yardımda bulunamadı ${ }^{152}$ Çatışmanın başlamasının üzerinden daha 15 dakika geçmemişti ki Fransız hattının başında yer alan iki geminin direkleri kırıldı. Diğerleri de ciddi şekilde hasar gördü. ${ }^{153}$ Sonuçta Nelson'un planı işe yaradı ve sadece 2 saat içerisinde Fransızların 5 savaş gemisi saf dışı bırakılabildi. ${ }^{154}$ Aşağıdaki belge İngilizlerin sahil ile Fransız gemileri arasına nasıl girdiklerini göstermektedir: ${ }^{155}$

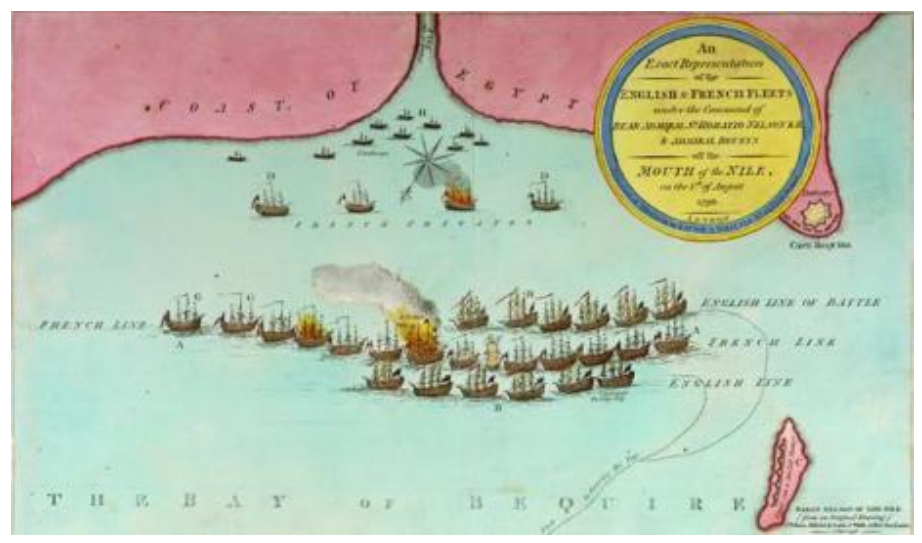

Savaş başladıktan bir süre sonra, Nelson'un oluşturduğu hatta yer almayıp muharebenin üzere harekete geçti. Ancak Culloden, Ada'nın kayalıklarına çarpıp karaya oturdu. ${ }^{156}$ Bununla beraber o zamana kadar Fransız Donanması'nın ileri kolu ezilmişti. ${ }^{157}$

Fransızların ileri hattının etkisiz hale getirilmesinin ardından, muharebe, merkezde yoğunlaştı. Hattın ortasında 120 topluk dev Orient bulunmaktaydı. Orient'ın önünde Fransız Donanması'nın en ağır gemilerinden 80 topluk Franklin ve hemen arkasında ise yine ağır gemilerden 80 topluk Tonnant yer almaktaydi. ${ }^{158}$ İngiliz gemileri, bu çok büyük Fransız gemilerine karşı top ve tüfek atışlarını artırdılar. Ancak çatışma sırasında İngiliz gemilerinden Bellerophon'un direği kırıldı ve sürüklenmeye başlayarak savaş dışı kaldı. ${ }^{159}$ Diğer İngiliz gemilerinin hedefinde ise özellikle Orient vardı. Bu dev gemide bulunan ve çatışmanın şiddetlenmesine rağmen güverteden ayrılmayan Fransız Komutan Brueys, İngilizlerin

\footnotetext{
${ }^{150}$ Clarke; McArthur, age, s. 473-476; Barker, age, s. 201; Hughes, age, Vol. VI, s. 353-354; Mahan, The Influence of..., Vol. I, s. 267-268; Mahan, The Life of..., Vol. I, s. 349; Hunt, age, s. 416-417; Southey, age, s. 114; Rodger, age, s. 477.

${ }^{151}$ Carrington; Jackson, age, s. 573.

${ }^{152}$ Rodger, age, s. 477.

${ }^{153}$ Southey, age, s. 117.

${ }^{154}$ Bright, age, Period III, s. 1221

${ }^{155}$ UK, TNA, DO, MPI 1/536 Number 6.

${ }^{156}$ The Times, October 3, 1798; Clarke; McArthur, age, s. 479; Cassell's History..., Vol. IV, s. 467.

${ }^{157}$ Hunt, age, s. 417.

${ }^{158}$ Mahan, The Life of..., Vol. I, s. 347; Keegan, age, s. 64.

${ }^{159}$ Hunt, age, s. 417.
} 
yoğunlaştırdığı ateşten kaçamadı ve ağır bir şekilde yaralandı. ${ }^{160}$ Geminin alt katına taşınmayı reddeden Brueys, son anlarında güvertede olmak istedi. Nitekim sadece 15 dakika kadar hayatta kalabildi. ${ }^{161} \mathrm{Bu}$ gelişme savaşın en kritik anlardan birisiydi. ${ }^{162}$ Kısa bir süre sonra ise Orient yanmaya başladı. İngilizler çok şiddetli bir şekilde Orient'1 ateş yağmuruna tuttukları için Fransız mürettebat buna karşılık veremedi. Yaz gecesi alevlerle aydınlandı. Yangın, cephane deposuna ulaşınca bu büyük gemi 22.00 civarında çok şiddetli bir gürültüyle infilak etti. ${ }^{163}$ Gemide bulunan binden fazla askerin pek çoğu bu büyük patlama sonucu hayatını kaybetti. ${ }^{164}$ Orient, içerisindeki değerli hazinelerle beraber suya gömüldü. ${ }^{165} \mathrm{Bu}$ dehşetli olay, her iki tarafta da, savaşın bir süre durmasına neden olacak kadar şaşkınlık yarattı. ${ }^{166}$ Aşağıdaki resim bu patlamayı tasvir etmektedir. ${ }^{167}$

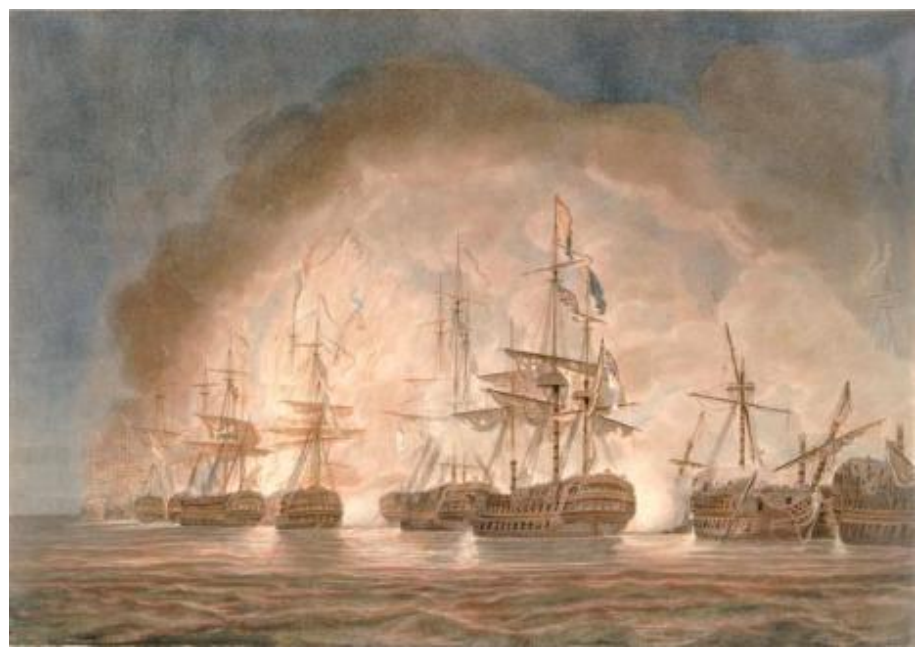

Fransızlar açısından diğer önemli bir gelişme ise, Orient'ın yanında savaşan Tonnant'ın kaybedilmesi oldu. Direği kırıldıktan sonra İngilizlerin eline geçen Tonnant'nn güvertesi, hayatını kaybeden Fransız askerlerinin cesetleriyle doluydu. ${ }^{168}$

Aşağıdaki tasvirde Nil Savaşı’nın nasıl cereyan ettiği görülmektedir. ${ }^{169}$

\footnotetext{
${ }^{160}$ The London Gazette Extraordinary, October 2, 1798; The Times, October 3, 1798; The Edinburgh Advertiser, October 5, 1798; Guizot; Witt, age, Vol. VI, s. 386. Amiral Blanquet'in ifadesine göre, isabet eden bir atış sonucu Brueys'in vücudu neredeyse ikiye bölündü. Clarke; McArthur, age, s. 481.

${ }^{161}$ Clarke; McArthur, age, s. 481-482; Southey, age, s. 118.

162 Thompson, age, s. 303.

163 Olaya şahitlik eden Vanguard'ın Kaptanı Edward Berry, patlamanın akşam 10.00 civarında gerçekleştiğini söylerken (Bkz. Berry, age, s. 26-27.), Barker bu saati 9.37 olarak göstermiştir. Bkz. Barker, age, s. 209. Bazı kaynaklar ise patlamanın saat 11.00'de yaşandığını yazmışlardır. Bkz. Cassell's History..., Vol. IV, s. 467.

${ }^{164}$ Grimshaw, age, s. 253.

${ }^{165}$ Tucker, age, s. 273.

${ }^{166}$ Clarke; McArthur, age, s. 482; Rodger, age, s. 477.

${ }^{167}$ Nicholas Pocock, PY7942-Royal Museums Greenwich / http://images.rmg.co.uk

${ }^{168}$ Guizot; Witt, age, Vol. VI, s. 386-387.

169 Yukarıdaki savaş tasviri, Ebukır Koyu'nu güneydoğu yönlü olarak resmetmektedir. Düşman hattına doğru yaklaşan İngiliz savaş gemileri alfabetik olarak belirtilmiştir. Bu gemilerin saldırıya geçtikten sonra Fransız gemileri karşısında aldıkları pozisyonlar ise, yine alfabetik olarak ve içi boş gemi şeklinde gösterilmiştir. Gidiş yolları da çizgilerle gösterilmeye çalışılmıştır: A Goliath, B Zealous, C Orion, D Audacious, E Theseus, F Vanguard, G Minotaur, H Bellerophon, I Defence, K Majestic, L Alexander, M Swiftsure, N Leander, O Culloden ve P Mutine. Fransız savaş gemileri ise rakamlarla gösterilmiştir: 1 Guerrier, 2 Conquerant, 3 Spartiate, 4 Aquilon, 5 Peuple Souverain, 6 Franklin, 7 Orient, 8 Tonnant, 9 Heureux, 10 Timoleon, 11 Guillaume Tell, 12 Mercure ve 13 Genereux. Frrkateynler: 14 Serieuse, 15 Artemise, 16 Diane ve 17 Lustice. Alert, Infanta ve Castor adlı havan
} 


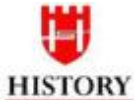

STUDIES

37

Volume 10

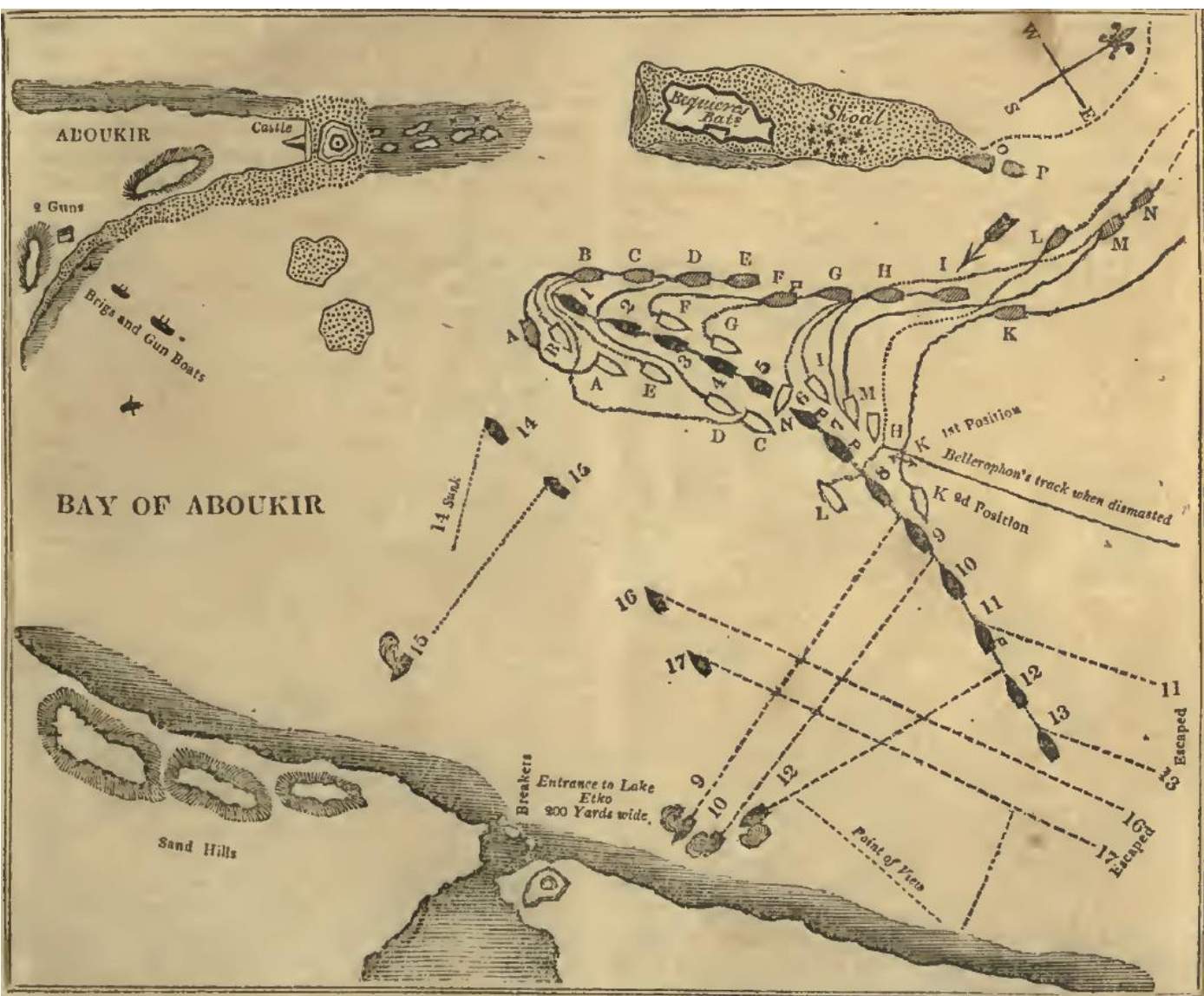

$\mathrm{Bu}$ şiddetli çatışmalar sırasında Nelson da başından ağır bir şekilde yaralandı. ${ }^{170}$ Yakınında bulunan Kaptan Berry, onu kollarına alarak geminin alt katına taşıdı. ${ }^{171}$ Ancak aldığı yaraya rağmen Nelson, bir süre sonra tekrar güverteye çıttı ${ }^{172}$ ve ardından Orient'ın mürettebatından kurtulanların bulunması için tekneler gönderilmesini emretti. ${ }^{173}$

Çatışmalar gece boyunca devam etti. Savaş, ancak sabah sona erdi. ${ }^{174} 12$ saat boyunca devam eden dehşetli bir muharebenin ardından 17 Fransız gemisinden 9'u İngilizlerin eline geçti. Bunlar, Guerrier, Conquerant, Spartiate, Aquilon, Peuple Souverain, Franklin, Tonnant, Heureux ve Mercure adlı savaş gemileriydi. Serieuse adlı fırkateyn, çatışmalar sırasında aldığı ağır hasar nedeniyle battı. Ayrıca alevlere teslim olduktan sonra infilak eden amiral gemisi Orient'a benzer şekilde, Timoleon adlı savaş gemisiyle Artemise adlı firkateyn de yanarak kullanılamaz hale geldi. Kaçmayı başarabilen 4 Fransız gemisi ise, Guillaume Tell ve

gemileri, Ebukır kalesinin bulunduğu sahil tarafında betimlenmiştir. Baines, age, Vol. I. (Söz konusu resmin yer aldığı sayfa 206 ile 207. sayfalar arasında yer almaktadır. Ancak herhangi bir sayfa numarası verilmemiştir.)

${ }^{170}$ Nelson'un sağ gözünün üzerindeki alın bölgesinde meydana gelen 3 inç $(7,62 \mathrm{~cm})$ uzunluğundaki kesik kemiğe kadar dayanmıştı. UK, TNA, ADM (Records of the Admiralty), 101/124/1. Ayrıca bkz. Clarke; McArthur, age, s. 483. Bu, son dört yıldaki üçüncü ciddi yaralanmasıydı. Carrington; Jackson, age, s. 573. Nelson, bir sene kadar önce kolunu kaybetmiști. Oliver Warner, The Battle of the Nile, Pickle Partners Publishing, 2017, s. 27. Nitekim 24 Temmuz 1797'deki bu yararlanmasının ardından 1798 Nisanı'na kadar aktif görevden uzak kaldı. Mahan, The Life of..., Vol. I, s. 317.

${ }^{171}$ Mahan, The Life of..., Vol. I, s. 351; Southey, age, s. 117.

${ }^{172}$ Thompson, age, s. 303.

${ }^{173}$ Hunt, age, s. 417; Cassell's History..., Vol. IV, s. 467.

${ }^{174}$ Savaş sona erdiğinde ertesi günün altısı olmuştu. Bright, age, Period III, s. 1221.

\section{Journal of History Studies}


Genereux adlı savaş gemileriyle Diane ve Lustice adlı firkateynlerdi. ${ }^{175}$

Çok şiddetli geçen Nil Savaşı'ndan doğal olarak İngiliz gemileri de nasibini aldı. Nelson'un donanmasında en fazla zarar gören gemiler Bellerophon ve Vanguard'dı. ${ }^{176}$ Nitekim gemilerinde meydana gelen hasarlar, Nelson'un, zarar görmeden kaçmayı başaran Fransız gemilerini kovalamaktan vazgeçmesine neden oldu. ${ }^{177}$ Ancak İngilizlerin kayıpları, Fransızlarınkiyle kıyaslanamazdı. Zira bu savaşta 5.225 Fransız deniz eri hayatını kaybetti. ${ }^{178}$ Esir düşenlerle beraber Fransızların kayb1 9.830'u buluyordu. ${ }^{179}$ İngilizlerin ölü ve yaralı sayısı ise sadece 895 'ti. 16 's1 subay, 46's1 piyade ve 156 'sı deniz eri olmak üzere toplam ölü sayısı yalnızca 218 'di. Yaralı sayısı ise, 37'si subay, 78'i piyade ve 562'si deniz eri olmak üzere toplam 677 kişiydi. ${ }^{180}$ Hayatını kaybedenlerden 30'u, yaralananlardan da 75 'i Vanguard'ın mürettebatındand. ${ }^{181} \mathrm{Bu}$ kesin başarı tablosu karşısında Nelson, "Zafer, bu sahneyi adlandırmak için yeterli bir kelime değil." demekten kendisini alıkoyamadı. ${ }^{182}$

Savaşın hemen ardından Nelson, elde ettiği zaferi haber vermek üzere Kaptan Edward Berry'yi, Kaptan Thompson'in idaresindeki Leander'le Britanya'ya gönderdi. Ancak savaştan sağlam kurtulmayı başaran Fransız savaş gemisi Genereux ile karşılaşan Leander, Fransızlar tarafından ele geçirildi. ${ }^{183}$ Dolayısıyla kesin haber ulaşana kadar başta İngiltere olmak üzere tüm Avrupa bir süre daha gelişmelerle ilgili söylentilerle yetinmek zorunda kald1. ${ }^{184}$ Zafer haberinin resmen İngiliz Denizcilik Bakanlığı'na ulaşması ise 2 Ekim'i buldu. Haberi getiren Mutine adlı brikle Londra'ya gelen Kaptan Capel oldu. ${ }^{185}$

Son olarak Nil Savaşı'nın denizcilik tarihine geçen oldukça dehşetli bir savaş olduğunu söyleyebiliriz. ${ }^{186}$ Sonuçta Fransız Donanması'nın 4'te 3'ü artık yoktu. ${ }^{187}$ Savaş, Fransızların tüm avantajlarına rağmen, İngilizlerin mutlak zaferiyle sona ermişti. ${ }^{188}$ Gerçekten de bu savaş, tüm bu dönemde yapılan deniz savaşları içerisinde en kesin ve belirleyici sonuca sahip olanlardan birisiydi. Napolyon ise ilk kez İngiltere'nin deniz gücünün tadına bakmış oldu.

${ }^{175}$ UK, TNA, DO, MPI 1/536 Number 6; The London Gazette Extraordinary, October 2, 1798; The Times, October 3, 1798; The Edinburgh Advertiser, October 5, 1798. Ayrica bkz. Baines, age, Vol. I, s. 208; Thoyras, age, Vol. II, s. 613; Barker, age, s. 215.

${ }^{176}$ Barker, age, s. 216.

${ }^{177}$ Bright, age, Period III, s. 1221; Rodger, age, s. 477. Sadece Zealous, bu savaştan ciddi bir yara almadan çımayı başard1. Cassell's History..., Vol. IV, s. 468.

${ }^{178}$ Clarke; McArthur, age, s. 484; Hughes, age, Vol. VI, s. 357.

${ }^{179}$ Cassell's History..., Vol. IV, s. 468.

${ }^{180}$ UK, TNA, DO, MPI 1/536 Number 6; The London Gazette Extraordinary, October 2, 1798; The Times, October 3, 1798; The Edinburgh Advertiser, October 5, 1798. Ayrica bkz. Clarke; McArthur, age, s. 484-485.

${ }^{181}$ İngilizlerden ölen ve yaralananların gemilere göre dağılımı şöyleydi: Goliath 21 ölü, 41 yaralı; Zealous 1 ölü, 7 yaralı; Orion 13 ölü, 29 yaralı; Audacious 1 ölü, 35 yaralı; Theseus 5 ölü, 30 yaralı; Minotaur 23 ölü, 64 yaral1; Bellerophon 49 ölü, 148 yaralı; Defence 4 ölü, 11 yaralı; Majestic 50 ölü, 143 yaralı; Alexander 14 ölü, 58 yaralı; Swiftsure 7 ölü, 22 yaralı; Leander 14 yaralı. UK, TNA, DO, MPI 1/536 Number 6; The London Gazette Extraordinary, October 2, 1798; The Times, October 3, 1798; The Edinburgh Advertiser, October 5, 1798.

${ }^{182}$ Cassell's History..., Vol. IV, s. 468; Clarke; McArthur, age, s. 484; Green, age, Vol. IV, s. 337.

${ }^{183}$ Hughes, age, Vol. VI, s. 358; Mahan, The Life of ..., Vol. I, s. 361.

${ }^{184}$ Rodger, age, s. 478. Mesela The London Chronicle adlı İngiliz gazetesinin 9 Ağustos 1798 tarihli sayısında, Malta'dan hareket eden Fransız Donanması'nın nerede olabileceği ile ilgili ihtimaller okuyucularla paylaşıldı. Bkz. The London Chronicle, August 9, 1798.

${ }^{185}$ The London Gazette Extraordinary, October 2, 1798; The Times, October 3, 1798; The Edinburgh Advertiser, October 5, 1798.

${ }^{186}$ Grimshaw, age, s. 253.

${ }^{187}$ Crowe, age, Vol. V, s. 48.

${ }^{188}$ Samuel Rawson Gardiner, The History of Nations England, Edited by Augustus Hunt Shearer, Vol. XI, P. F. Collier \& Son Publishers, New York 1913, s. 549. 
Ama bunun sonuncu olmayacağını da belirtmek gerekir. ${ }^{189}$

\section{Savaşın Yankıları}

Napolyon'un denizaşırı planlarının bir sonucu olarak İngiliz ve Fransız Donanmalarının karşı karşıya geleceğine ve bu karşılaşmanın da oldukça önemli neticeler doğuracağına şüphe yoktu. Yaşanacak savaş, öncelikli olarak denizlerde İngilizlerin mi, yoksa Fransızların mı üstün olduğunu gösterecekti. Aynı zamanda Avrupa'da yeniden başlayan mücadelenin sonucunu ve Mısır'ın, hatta Hindistan'ın kimin olacağını belirleyecek kadar önemliydi. Bu sebeplerle Fransızlara karşı kazanılan zaferin haberi, İngiltere'de, doğal olarak büyük bir coşku ve sevinçle karşılandi.

En başta, bu önemli galibiyetin sağlanmasında büyük rol sahibi olan Nelson, "Nil'in Baronu" unvanı verilerek onurlandırıld1. ${ }^{190}$ Ayrıca kendisine yıllık 2.000 Pound maaş da bağland $1{ }^{191}$ Şüphesiz bu zafer, Nelson'un isminin Avrupa'da bilinmesini de sağladı. ${ }^{192}$ Nitekim bu başarının ardından Nelson, tüm Avrupa'da bir kahraman olarak görüldü. ${ }^{193}$

Nil Savaşı'ndan birkaç ay sonra, 20 Kasım 1798'de, İngiliz kamuoyunun hoşnutsuzluğunun Nelson'un zaferiyle azaldığı bir sırada İngiltere Parlamentosu yeniden çalışmalarına başladı. ${ }^{194}$ Parlamento'nun açılışı münasebetiyle Kral tarafindan gönderilen mesaj, Nil Savaşı'da gösterdikleri kahramanlıklardan dolayı başta Nelson olmak üzere İngiliz denizcilerine yönelik takdir ve iltifatlarla doluydu. Söz konusu yazıda, Nil zaferi, Britanya İmparatorluğu'nun en önemli çıkarlarına karşı yapılmış bir girişimi akamete uğratan ve Avrupa'nın kurtuluşu için diğer güçleri harekete geçirecek olan bir gelişme olarak tanımland1. ${ }^{195}$

Bu tanım aslında oldukça doğruydu. Zira Mısır'ın işgali, Doğu'daki İngiliz egemenliğini ve ticaretini yok etmek için tasarlanmış bir adımdı. Bu tasarı doğrultusunda hareket eden Napolyon, Piramitlerin yakınında Memluk kuvvetlerini kesin bir yenilgiye uğratmış ve Mısır'da belli bir hâkimiyet tesis etmeyi de başarmıştı. Ancak Nil Savaşı'nın kaybedilmesi, Napolyon'un Misır seferinden beklentilerini ciddi şekilde etkiledi. ${ }^{196}$

\footnotetext{
${ }^{189}$ Hazen, age, s. 255.

${ }^{190}$ The Parliamentary Register; Or, History of the Proceedings and Debates of the Houses of Lords and Commons: Containing an Account of the Most Interesting Speeches and Motions; Accurate Copies of All the Protests, and of the Most Remarkable Letters and Papers; Together with the Most Material Evidence, Petitions, \&c. Laid Before and Offered to either House During the Third Session of the Eighteenth Parliament of Great Britain, Vol. VII, Printed for J. Debrett, opposite Burlington House, Piccadilly, London 1799, s. 61; The Edinburgh Advertiser, October 9, 1798.

${ }^{191}$ The Parliamentary Register, s. 61, 67. Doğu Hindistan Sirketi de, Hindistan'daki güvenliklerini garanti altına alan Nelson'a karşı şükranlarını 10.000 Pound para ödülüyle gösterdi. Mahan, The Life of ..., Vol. I, s. 363.

${ }^{192}$ Knight, The Pursuit of ..., s. XXXIV.

${ }^{193}$ John Sugden, Nelson: A Dream of Glory, Henry Holt and Company, New York 2004, s. 121. Kahramanları Horatio Nelson'un 1805'teki ölümü, Napolyon'la mücadele eden tüm Avrupalılar tarafindan hiçbir zaman unutulmayacak olaylardan birisi olarak kabul edildi. Age, s. 1. Ölümünün üzerinden iki asır geçen İngilizlerin milli kahramanı Nelson, bugün Avrupa'da, hakkında kitaplar yazılan, belgeseller çekilen ve tiyatro eserleri sergilenen önemli bir tarihi şahsiyet olarak kabul edilmektedir. Richard Harding, "Neglect or Treason: Leadership Failure in the Mid-Eighteenth-Century Royal Navy", Naval Leadership and Management, 1650-1950: Essays in Honour of Michael Duffy, Edited by Helen Doe and Richard Harding, Boydell Press, UK 2012, s. 43.

${ }^{194}$ Hughes, age, Vol. VI, s. 362.

195 The Parliamentary Register, s. 1-3. Türkiye ile Rusya'dan da bahsedilen söz konusu mesajda, bu ülkeler, Fransa'nın boyunduruğu altında çırpınan ve tek dertleri güvenlikleri ve onurları olan tüm ülkeler için örnek olarak gösterildi. Age, s. 2. Kazanılan deniz zaferi dolayısıyla Avam Kamarası'ndan yapılan resmi teşekkür için bkz. Devon Archives and Local Studies Service (South West Heritage Trust), 152M/C1798/ON4.

${ }^{196}$ Gleichen, age, s. 75.
} 
Bu noktada Napolyon'un Fransızlar açısından yaşanan bu faciadaki payına değinmek gerekir. Zira donanmanın, Fransız ordusunu koruyacak şekilde pozisyon alması emrini veren o idi. Her ne kadar bu konudaki sorumluluğunu sonradan inkâr etmiş olsa da, donanmaya ne olacağ 1 konusunda yeterince hassas davranmadığ 1 da ortadayd $1{ }^{197}$ Hâlbuki karada kazanılacak zaferlerin, denizde elde edilecek başarılarla desteklenmesi şart görünüyordu. Bunun başarılamaması ise Napolyon'a oldukça pahalıya mal oldu.

Öncelikle, Fransız Donanması'nın imha edilmesi Napolyon'un Avrupa karasiyla olan iletişiminin tamamen kesilmesi sonucunu doğurdu. ${ }^{198}$ Zira Akdeniz hâkimiyeti tamamen İngiliz Kraliyet Donanması'nın eline geçti. ${ }^{199}$ İngiliz Donanması'nın Mısır'a uyguladığı abluka ise, Napolyon'un, gerek Fransa'daki gerekse tüm Avrupa'daki gelişmelerden haber alabilmesini imkânsiz hale getirdi.

İngilizlerin kesin olarak denizlere hâkim olmas1 ${ }^{200}$, sadece anakarayla iletişimin kesilmesine değil; ama aynı zamanda Fransız ordusunun Mısır'da kilit altında kalmasına da neden oldu. ${ }^{201}$ Zira Fransızların kayıpları sadece savaş gemileriyle sınırlı değildi. Brueys'in İskenderiye limanının sığ sularında güvence altına almaya çalıştı̆̆ çok sayıdaki nakliye ve ikmal gemisi İngilizler tarafından imha edildi. ${ }^{202}$ Fransızların ellerinde kalan çok az sayıdaki gemiyle, Akdeniz'i kontrol altında tutan Kraliyet Donanması'nı bir şekilde geçip Fransa'ya dönebilmeleri ya da oradan herhangi bir yardım alabilmeleri mümkün görünmüyordu. $\mathrm{Bu}$ durum, Napolyon'un önündeki seçenekleri oldukça azalttı. Bir kere Hindistan'1 ele geçirme ve Doğu'da büyük bir Fransız İmparatorluğu tesis etmesiyle ilgili hayallerini gerçekleştirmesi artık çok daha zordu. ${ }^{203}$ Zira düşman bir ülkede istikrarsız kaynaklara mahkûm kalmışt. ${ }^{204}$ Tabi bu durum Mısır'ı elde tutmasını da oldukça güçleştirdi. Nelson'un zafer haberi, Kahire sokaklarında heyecana ve başarısız bir isyan girişiminin yaşanmasına neden oldu. ${ }^{205}$ Napolyon'un işgaline karşı başlayan ve birkaç yüz Fransız askerinin ölümüyle sonuçlanan halk hareketi, yerel halktan en az 5 bin kişinin katledilmesiyle bastırılabildi. ${ }^{206}$

Nelson'un zaferi, Avrupa'da da heyecan uyandırdı. Donanmalarının yok edilmesi, Fransızların yenilmezliğini de yok etti. Eski müttefikler, Fransa'ya karşı tekrar harekete geçme fırsatı doğduğunu gördüler. ${ }^{207} \mathrm{Bu}$ başarının meyvelerini toplamak isteyen İngiltere ${ }^{208}$,

\footnotetext{
${ }^{197}$ Rodger, age, s. 476.

${ }^{198}$ Crowe, age, Vol. V, s. 48; Green, age, Vol. IV, s. 337.

${ }^{199}$ Emsley, age, s. 57.

${ }^{200}$ Nil Savaş1 sonucunda rakipsiz kalan İngiliz Kraliyet Donanması, denizlerin kontrolünü bir süre için tamamen eline almış oldu. Roy Adkins, Nelson's Trafalgar: The Battle That Changed the World, Penguin Books, New York 2005, s. 3. Ayrıca Kraliyet Donanması'nın, Napolyon'un görkemli imparatorluğunun çöküşünde ve savaşların sonucunda nihai olarak galip gelen tarafın Britanya olmasında büyük rolü olduğunu belirtmek gerekir. Martin Robson, History of the Royal Navy, The Napoleonic Wars, I. B. Tauris, London 2014, s. 2. Aslinda Kraliyet Donanması, daha XVII. yüzyılda, İngilizlerin savaşlarda üstünlük kurmasını sağlayan yırtıcı bir araç haline gelmeye başlamıştı. Keegan, age, s. 61.

${ }^{201}$ Headlam, age, s. 366; Stewart Ross, Events and Outcomes: The French Revolution, Evans Brothers, London 2002, s. 44.

${ }^{202}$ Cassell's History..., Vol. IV, s. 468. Nil Savaşı'ndaki kayıplar, Fransız Donanması üzerinde gerçekten de yıkıcı bir etki meydana getirdi. Adkins, age, s. 3.

${ }^{203}$ Gardiner, age, Vol. XI, s. 549.

${ }^{204}$ Jervis, age, s. 588.

${ }^{205}$ Green, age, Vol. IV, s. 337.

206 Jervis, age, s. 588; Cassell's History..., Vol. IV, s. 468.

${ }^{207}$ Emsley, age, s. 57.

208 İngiliz bakanları ve diplomatları, Fransa'ya karşı ikinci bir ittifak oluşturulması için Avrupa'daki diğer saraylarla ivedilikle müzakerelere giriştiler. Kurulan bu yeni Koalisyon'un ve İngiltere'nin savaş politikası, seleflerininkiyle aynı çizgideydi. Emsley, age, s. 57. İçişleri Bakanı Henry Dundas ise, 1799 yılında, tüm dünya ticaretinin ana anahtarı olarak gördüğü Mısır'da kesin bir zafer kazanılması konusunda Başbakan Pitt üzerinde güçlü bir şekilde
} 
Avusturya $^{209}$ ve Rusya ${ }^{210}$ devletlerini yanına alarak yeni bir Koalisyon kurdu. ${ }^{211}$ Napoli de, bu ittifaka dâhil olarak Kasım 1798 'de Fransa'ya karşı savaş ilan etti. ${ }^{212}$ Napolyon'un Mısır'a saldırması, en başta toprağın sahibi olan Osmanlı Devleti'ni ilgilendiriyordu. Bu işgal hareketi, Osmanlı Devleti'nin de bu ittifak grubuna dâhil olmasına neden oldu. ${ }^{213}$ Aslında III. Selim, işgal girişiminin başında Fransa'ya karşı savaş ilanı konusunda aceleci davranmamıştı. Ancak Nil Savaşı, bu konuda teşvikkâr bir gelişmeydi. ${ }^{214}$ Nitekim savaş ilanı, Fransız Donanması'nın Ebukır'da yok edilmesinden sonra gerçekleşti. ${ }^{215}$

Tüm bu olumsuzluklara rağmen Napolyon'un umutlarından hemen vazgeçtiği söylenemez. Napolyon'a göre bu, "üstün karakterdekilerin kendilerini göstermeleri gereken bir zaman" $\mathrm{d}_{1}{ }^{216} \mathrm{O}$ da, gelişmeler karşısında beklemek yerine Suriye'yi ele geçirmeye karar verdi. Zira kaynağa ve morale ihtiyacı vardı. Yeni zaferlerle ordusunun özgüvenini tekrar sağlayabilirdi. Üstelik zihnindeki Doğu'yu ele geçirmekle ilgili büyük planlar hâlâ canlıydı. Suriye, daha doğudaki askerî operasyonlar için çok elverişli bir üs olabilirdi. ${ }^{217}$ İstanbul'u alabilir ve bu şekilde Avrupa'yı bir çevirme hareketiyle fethedebilirdi. Ya da ikinci bir "Büyük İskender" olur ve İngilizleri Hindistan'dan sürebilirdi. O’na göre, Suriye'nin ele geçirilmesi İstanbul'un veya Delhi'nin fethedilmesinin yolunu açacaktı. Nitekim Kızıldeniz'in kıyılarından, Maisur Sultanı Tipu Sahib'e kendi ordusunu beklemesini yazdı. Bütün bunların yanında Suriye’yi ele geçirerek İngiliz Donanması'nın Doğu Akdeniz'deki levazım kaynağını

baskı yapıyordu. Buranın işgal edilmesi sayesinde İngiliz kaynakları dünyanın çeşitli yerlerine yönlendirilebilir ve bu suretle Fransa'ya ve Fransızların ticaretine zarar verilebilirdi. Eric J. Evans, William Pitt the Younger, Routledge, London 1999, s. 52.

${ }^{209}$ Campo Formio Antlaşması ile küçük düşen ve askerlerini de terhis etmemiş bulunan Avusturya, ordusunun mevcudunu daha da artırdı ve İtalya ile İsviçre'deki kayıplarına karşı Fransa'dan tazminat talep etti. Bright, age, Period III, s. 1221. Avusturya, Ruslara yapacağı yardım ile Fransa'yı işgal etmeyi ve direktörleri iktidardan düşürmeyi umuyordu. Neely, age, s. 242.

${ }^{210} 1796$ yılının sonlarından itibaren Rusya, Avrupa savaşlarına bulaşmaktan kaçınabilmeyi uman II. Katerina'nın oğlu I. Paul tarafindan yönetilmeye başlamıştı. Ancak Paul, Fransa'daki İhtilal rejiminin doymak bilmez yayılma politikalarından endişe duyuyordu. Rusya, Fransa'nın Doğu Akdeniz'de daha büyük bir güç haline gelmesinden de doğal olarak korkuyordu. Kendisini Malta Şövalyelerinin koruyucusu olarak gören Paul, Ada'nın Napolyon tarafından işgal edilmesinin ardından Fransa'nın karşısına çıkmaya karar verdi. Neely, age, s. 242.

211 Böylece İkinci Koalisyon Savaşları başlamış oldu. Avusturya, İngilizlerin parasal yardımıyla yeni bir ordu hazırladı ve Fransızları Ren Nehri'nin ötesine sürdü. Fransızların durumundan yararlanan İngilizler de Minorka'yı işgal ettiler. Keith Feiling, A History of England, McGraw-Hill, New York 1948, s. 749.

${ }^{212}$ Fransa'nın Avrupa'daki zayıflamış pozisyonundan (Fransa'nın işgali altındaki birçok ülkede 1798 ve 1799 yıllarında isyanlar çıktı.) yararlanan Napoli, Fransa'nın himayesindeki Roma Cumhuriyeti'ne saldırdı ancak başarı sağlayamadı. Bunun üzerine Fransa, Napoli'yi işgal etti ve burada Parthenopean Cumhuriyeti'ni kurdu. Neely, age, s. 242.

${ }^{213}$ Bonnechose, age, Vol. IX, s. 307. 1799 yılında kurulan İkinci Koalisyon, Rusya, Avusturya, Büyük Britanya, Türkiye, Portekiz ve Napoli devletlerinden oluşuyordu. Linda S. Frey; Marsha L. Frey, The French Revolution, Greenwood Publishing Group, Westport 2004, s. 14.

${ }^{214}$ Hunt, age, s. 418.

215 Osmanlı Devleti'nin Fransa'ya savaş ilan ettiği ve Fransız elçisiyle sefaretteki tüm çalışanların Yedikule Hisarı'na gönderildikleri, The Edinburgh Advertiser adlı resmi gazetenin 5-9 Ekim tarihlerini kapsayan sayısında İngiliz halkına duyuruldu. Bkz. The Edinburgh Advertiser, October 9, 1798. Osmanlı Devleti, Misır'1 geri almak amacıyla Rusya'yla dahi ittifak ettiği gibi, biri Rodos'ta diğeri Şam'da olmak üzere Napolyon'a karş1 iki ordu hazırladı. Bkz. Enver Ziya Karal, Osmanlı Tarihi, Nizam-ı Cedid ve Tanzimat Devirleri (1789-1856), Cilt V, Türk Tarih Kurumu Yayınları, Ankara 1988, s. 31-38; Jervis, age, s. 589.

${ }^{216}$ Hazen, age, s. 256.

${ }^{217} 1799$ Şubatı'nda harekete geçen Napolyon, önce Suriye sınırında müstahkem bir şehir olan El-Ariş’i ele geçirdi. İlerlemeyi sürdüren Napolyon, Mart ayında Yafa üzerine saldırdı ve burasını kuşatma altına aldı. Adına büyük bir utanç bulaştıracak şekilde 3 bin kadar esiri soğukkanlılıkla katlettiği yer de burası oldu. Napolyon'un doğruluğunu kabul etmekten çekinmediği ama boş yere kendisini mazur ve haklı çıkarmaya çalıştığı bu eylem şüphesiz ki son derece barbarca bir hareketti. Neely, age, s. 242. Jervis, katledilen askerlerin sayısını daha az olarak göstermiştir. Bkz. Jervis, age, s. 589. 
da sona erdirecekti. ${ }^{218}$ Ancak 1799 baharında Akka'da ${ }^{219}$ uğradığı yenilgi sonucunda hızlı bir şekilde Mısır'a çekilmek zorunda kaldı. ${ }^{220}$

Napolyon, oldukça yıpratıcı bir yolculuktan sonra Mısır'a dönebildi. ${ }^{221} 1799$ Temmuz' unda ise Ebukır'daki Türk kuvvetleriyle karşı karşıya geldi. Burada başarılı olsa da ${ }^{222}$ tüm bu mücadelelerin neticesinde askerleri tamamen tükendi. Ayrıca ciddi anlamda para ve erzak sıkıntısı yaşıyordu. Bu sırada direktörlerin yönetiminde işlerin iyi gitmediğini ve Fransız ordusunun Avrupa'da yenilgiler almaya başladığını öğrendi. ${ }^{223}$ Bunun üzerine aldatıcı bir şekilde Mısır'ın fethi işinin tamamlandığını ilan etti ve vakit kaybetmeden Fransa'ya geçmek üzere Ağustos ayında Mısır'dan ayrıldı. Doğu'nun fatihi olarak göz kamaştırıcı askerî ünüyle kritik bir zamanda Fransa'ya dönen Napolyon, bir başka Jakoben rejimin oluşturduğu korkunç tehlike, müzmin terör ve yıkıcı savaş karşısında ülkenin kurtarıcısı olarak görüldü ${ }^{224}$ ve "Birinci Konsül" adıyla iktidara geçti. ${ }^{225}$ İngilizler ise 1801 Martı'nda Misır'a çıkarma yaptılar. İhtilal Savaşları'daki en başarılı İngiliz kara operasyonu olarak değerlendirebileceğimiz bu askerî harekâtın sonucunda Mısır'daki Fransız ordusu teslim olmak zorunda kaldi. ${ }^{226}$

${ }^{218}$ Hunt, age, s. 418.

219 Akka'nın kaderi, Napolyon'un kaderini belirleyecek kadar önemliydi. Fransızlar, burasını ele geçirmek için uzun süre umutsuz girişimlerde bulundular. Hunt, age, s. 419. Savunmayı başarılı bir şekilde yöneten Cezzar Ahmet Paşa'nın emrindeki Türk kuvvetleri bu süreçte Amiral Sidney Smith komutasındaki İngiliz Donanması tarafından ikmal ediliyordu. Gardiner, age, s. 838. Son derece şiddetle ve ustalıkla idare edilse de kuşatma sonuçta başarısız oldu. Her saldırı kahramanca püskürtüldü. Akka, zapt edilemez olduğunu kanıtladı. Bu şekilde Napolyon'un Doğu'ya hâkim olmakla ilgili müphem hayali de başarısızlığa mahkûm oldu. Jervis, age, s. 589.

220 Gleichen, age, s. 75.

221 Napolyon, kavurucu kumların üstünde çaresizlik ve yılgınlık içerisinde gerçekleşen bir yürüyüşle 300 mili 28 günde geçerek ordusunu Kahire'ye çekti. Bu yürüyüş sırasında 5 bin askerini kaybetti. Hazen, age, s. $256-257$.

222 Fransiz ordusu, 14 Haziran'da yeniden Kahire'ye girdi. İbrahim ve Murat Beyler, Yukarı Misır'da heyecan uyandıran yeni bir saldırı hareketinde bulundular. Bu taarruz, Rodos'tan gelip 11 Temmuz'da Ebukır'a çıkan 18 bin kişilik Türk ordusu tarafından destekleniyordu. Ancak Napolyon, Ebukır'daki Türk askeri kampına 25 Temmuz'da hücum etti. Ebukır'da yaşanan bu savaş, Napolyon'un Mısır Seferi’ndeki son başarısı oldu. Karal, age, s. 41; Jervis, age, s. 589.

${ }^{223}$ Napolyon, İngilizlerin uyguladığı abluka nedeniyle Avrupa'daki gelişmelerden haber alamıyordu. Neely, age, s. 243. Ancak İngiliz Komutan Sidney Smith, Avrupa'daki gelişmelerden haberdar olmasını ve Fransız ordusunun tehlikeli ve vahim durumunu görmesini sağlayacak gazeteler yolladı. Avrupa'nın Fransa aleyhine birleştiğini bu gazetelerden öğrenen Napolyon, ordusunu bırakarak Fransa'ya dönmeye karar verdi. Hunt, age, s. 419.

${ }^{224}$ Headlam, age, s. 366. Aslında Misır'a yaptığı yorucu ve yıpratıcı sefer, Napolyon ile iktidar arasında bir engel gibi görünüyordu. A Critical Dictionary of the French Revolution, Edited by François Furet and Mona Ozouf, Translated by Arthur Goldhammer, Harvard University Press, Cambridge, Massachusetts, London 1989, s. 277. Buna rağmen Mısır'daki başarısızlığı görmezden gelindi. 9 Ekim 1799'da Fréjus'un güney sahiline gizli bir şekilde çıkan Napolyon, basın ve kamuoyu tarafından İtalya fatihi, Campo Formio Barışı'nın sağlayıcısı ve Fransa adına Avrupa'ya onurlu bir barış kabul ettirebilen bir kişi olarak aşırı coşkulu bir şekilde karşılandı. George Rudé, The French Revolution, Grove Press, New York 1991, s. 125. Gerçekten de Fransız kamuoyu, Napolyon'u, Fransa'nın birliğini, düzenini ve refahını sağlayacak başarılı bir fatih olarak görüyordu. Zira Fransa, İhtilal'den bu yana tükenme derecesine gelmişti. Bu şartlarda Napolyon'un direktörleri devirip iktidara gelmesi zor olmadı. Bonnechose, age, Vol. IX, s. 312. Fransa'nın başına geçtikten sonra ise, Napolyon, geleceğin büyük imparatorluğunu kurmak için ülkenin hâlihazırdaki vatanseverlik ve savaş sevgisiyle ilgili ateşli duygularını nasıl kullanması gerektiğini iyi gördü. Bunun için de geçmişin yıpranmış düşünceleri ve partilerini bir tarafa bırakması gerektiğini anladı. George William Kitchin, A History of France, Vol. III, Clarendon Press, Oxford 1877, s. 507.

225 Thompson, age, s. 303.

226 Jeremy Black, George III: America's Last King, New Haven and London, Yale University Press, 2008 , s. 371. İngilizlerin askerî başarıları hakkında geniş bilgi için bkz. Piers Mackesy, British Victory in Egypt, 1801: The End of Napoleon's Conquest, Routledge London and New York 1995. 


\section{Sonuç}

Nil Deniz Savaşı, İngilizlerin Fransızlara karşı elde ettikleri tartışılmaz zaferle sonuçlandı. $\mathrm{Bu}$ başarının elde edilmesinde ne İngiliz gemilerinin büyüklükleri ne de içlerindeki asker ve silah sayıları önemli bir rol oynadı. Savaşın kazanılmasındaki en önemli faktör, İngilizlerin uyguladıkları savaş stratejisi oldu. Amiral Brueys'in Ebukır Koyu'nda aldığ 1 savaş pozisyonunun ve sahip olduğu büyük gemilerin önemli bir avantaj gibi göründüğüne şüphe yoktu. Ancak Fransız Amiral'in savaşın muhtemel senaryosuyla ilgili öngörüsü doğru çıkmadı. Brueys'in beklentisinin aksine, Amiral Nelson, donanmaların paralel hatlar oluşturup çarpışmaları usulünü uygulamadı. Bunun yerine kıyı ile Fransız gemileri arasına girip çift taraflı saldırı gerçekleştirebileceği bir planı tercih etti. Bu planın hayata geçirilebilmesi ise Fransızların tüm üstünlüklerini boşa çıkardı. Üstelik avantaj gibi görünen Fransız gemilerinin demirli vaziyette savaşmaları da yarardan çok zarar getirdi. Zira gemilerin hareket kabiliyetleri düştüğü gibi, birbirlerinin yardımına gidebilmeleri de mümkün olmadı. Bu durumda Fransızların ağır bir yenilgi almaları kaçınılmaz hale geldi. Tüm bunlar, zaferin kazanılmasında asker sayısından ziyade nitelik ve tecrübenin, gemi ve top sayısından ziyade ise doğru strateji ve kararların daha önemli olduğunun açıkça ispatı oldu.

Savaşın galip tarafı İngiltere'nin zaferin meyvelerini toplaması doğaldı. Bu zafer sayesinde İngilizler, öncelikli olarak Napolyon'un kontrol altına almak istediği "imparatorluk yolu"nu ve dolayısıyla servetlerinin en önemli kaynağı olan Hindistan'ı muhafaza etmeyi başardılar. Zira denizlerde etkisiz hale gelen Fransızların Doğu'ya uzanması artık pek mümkün değildi. En önde gelen rakiplerini saf dışı bırakan İngilizlerin denizlerdeki üstünlügü tartışmasız hale geldiği gibi, Akdeniz'in kontrolü de tamamen ellerine geçti. Bu zafer aynı zamanda Fransızlar karşısında yalnız kalmış olan İngilizlere, Avrupa'daki diğer güçleri de harekete geçirme imkânı sağladı. Nitekim İngiltere, bu galibiyetin yarattığı heyecanla Fransa' ya karşı yeni bir koalisyon oluşturmayı başardı.

Fransa açısından ise bu mağlubiyetin oldukça pahalıya mal olduğunu söyleyebiliriz. Aslında Fransızların, ister doğrudan İngiltere'ye yapılacak askerî bir harekât sırasında olsun, isterse sömürgelerini hedef alan bir girişim içerisinde olsun, İngilizlerin askeri güçlerinin temelini teşkil eden Kraliyet Donanması'yla karşı karşıya gelmeleri kaçınılmazdı. Mısır Seferi gerçekleşmeseydi bile, İngilizlerin savaş dışı bırakılması için denizlerdeki gücünün kırılması şarttı. Önemli olan Fransızların buna hazır olup olmadıklarıydı. Nil Savaşı bu sorunun cevabını verdi ve kimin denizlerde üstün olduğunu açıkça gösterdi. Bu gerçek ise öncelikli olarak Mısır Seferi'nin kaderini etkiledi. Mısır'a sıkışan ve Fransa'yla bağlantısı kesilen Napolyon'un yapabileceği şeyler oldukça sınırlandı. Sonuçta Fransızlar, ne yeni bir sömürge elde edilebildiler ne de Hindistan'a giden yolu kontrol altına alabildiler. Aksine Akdeniz hâkimiyetini tamamen İngilizlere bırakmak zorunda kaldılar. Malta Adası bir süre için Fransızların eline geçmiş olsa da, denizlerdeki güçlerinin kırılması Ada'nın korunmasını da imkânsız hale getirdi.

Fransızlar, İngilizleri savaş dışı bırakamadıkları gibi, bir de karşılarında yeni bir Koalisyon buldular. Napolyon'un Malta'ya saldırması Rusya'ya, Misır'a saldırması ise Osmanlı'ya karşı atılmış düşmanca adımlardı. Nitekim bu iki devlet ittifak yapıp Fransa'ya karşı birlikte hareket ettiler. Nil Savaşı'nın sonucu ise ortak düşmana karşı savaş açma konusunda teşvikkâr bir haberdi. Ancak Osmanlı Devleti'nin, Nil Savaşı'nın sonucundan bağımsız olarak, Fransa'nın saldırısına karşı her hâlükârda karşı koyacağını ve topraklarını korumaya çalışacağını da belirtmek gerekir. 


\section{Kaynakça}

\section{I- Arşiv Belgeleri}

A. United Kingdom Devon Archives and Local Studies Service (South West Heritage Trust)

152M/C1798/ON4.

\section{B. United Kingdom Shropshire Archives}

$146 / 27$.

C. United Kingdom Somerset Heritage Centre (South West Heritage Trust) $\mathrm{DD} \backslash \mathrm{SAS} \backslash \mathrm{C} / 795 / \mathrm{SX} / 45$.

\section{United Kingdom The National Archives}

Dominions Office, Maps and Plans, MPI 1/536 Number 6.

Foreign Office, 70/11 Folios 188-9.

Records of the Admiralty, 101/124/1.

\section{E. United Kingdom West Sussex Record Office}

Buckle/223.

\section{F. United Kingdom Parliament Documents}

The Parliamentary Register; Or, History of the Proceedings and Debates of the Houses of Lords and Commons: Containing an Account of the Most Interesting Speeches and Motions; Accurate Copies of All the Protests, and of the Most Remarkable Letters and Papers; Together with the Most Material Evidence, Petitions, \&c. Laid Before and Offered to either House During the Third Session of the Eighteenth Parliament of Great Britain, Vol. VII, Printed for J. Debrett, opposite Burlington House, Piccadilly, London 1799.

The Speeches of the Right Honourable William Pitt, in the House of Commons, Vol. III, The Third Edition, Printed for Longman, Hurst, Rees, Orme, and Brown, London 1817.

\section{II- Gazeteler}

The Edinburgh Advertiser, Published by Authority, October 5, 1798; October 9, 1798.

The Glasgow Advertiser, September 18, 1798.

The London Chronicle, August 9, 1798.

The London Gazette Extraordinary, Published by Authority, October 2, 1798.

The Times, October 3, 1798.

\section{III- Hatıratlar}

BERRY, Edward, An Authentic Narrative of the Proceedings of His Majesty's Squadron: Under the Command of Rear-Admiral Sir Horatio Nelson, from its Sailing from Gibraltar to the Conclusion of the Glorious Battle of the Nile; Drawn up from the Minutes of an Officer of Rank in the Squadron, The Second Edition, T. Cadell, Jun. and W. Davies, (Successors to Mr. Cadell), London 1798. 


\section{IV- Kaynak, Araştırma ve İnceleme Eserleri}

A Critical Dictionary of the French Revolution, Edited by François Furet and Mona Ozouf, Translated by Arthur Goldhammer, Harvard University Press, Cambridge, Massachusetts, London 1989.

ADAMS, Ephraim Douglass, The Influence of Grenville on Pitt's Foreign Policy 17871798, Carnegie Institution of Washington, Washington 1904.

ADKINS, Roy, Nelson's Trafalgar: The Battle That Changed the World, Penguin Books, New York 2005.

; ADKINS, Lesley, The War for all the Oceans: From Nelson at the Nile to Napoleon at Waterloo, Penguin Books, London 2008.

Annals of the Life of the Right Honourable William Pitt, Printed by B. Graves-Sold by $\mathrm{H}$. Maxwell, Philadelphia 1806.

BAINES, Edward, History of the Wars of the French Revolution from the Breaking out of the War in 1792 to the Restoration of a General Peace in 1815; Comprehending the Civil History of Great Britain and France during that Period, Vol. I, Printed for Longman, Hurst, Rees, Orme and Brown, London 1817.

BARKER, Matthew Henry, The Life of Nelson Revised and Illustrated, With Original Anecdotes, Notes, Etc., Frederic Shoberl, London 1836.

BLACK, Jeremy, George III: America's Last King, New Haven and London, Yale University Press, 2008.

BLAKE, Nicholas; LAWRENCE, Richard, The Illustrated Companion to Nelson's Navy, Stackpole Books, 2005.

BONNECHOSE, Emile de, France, Vol. IX, Revised and Edited by Fred Morrow Fling, The H. W. Snow and Son Company, Chicago 1910.

BRIGHT, James Franck, A History of England, Period III, Constitutional Monarchy William and Mary to William IV. 1689-1837, E. P. Dutton and Co., New York 1889.

CARRINGTON, Charles Edmund; JACKSON, John Hampden, A History of England, Cambridge University Press, Cambridge 1932.

Cassell's Illustrated History of England - From the Fall of Marlborough to the Peninsular War, Vol. IV, The King's Edition Cassell and Company Limited, London, New York, Toronto and Melbourne 1909.

CLARKE, James Stanier; MCARTHUR, John, The Life of Admiral Lord Nelson, K. B.; From His Lordship's Manuscripts, Printed by T. Bensley for T. Cadell and W. Davies, London 1810.

CROWE, Eyre Evans, The History of France, Vol. V, Longmans, Green and Co., London 1868.

DOYLE, William, The Oxford History of the French Revolution, Oxford University Press, Oxford 1989.

EMSLEY, Clive, Britain and French Revolution, Routledge, Abingdon Oxon 2014.

EVANS, Eric J., William Pitt the Younger, Routledge, London 1999. 
FEILING, Keith, A History of England, McGraw-Hill, New York 1948.

FITCHETT, William Henry, Nelson and his Captains: Sketches of Famous Seamen, Smith, Elder \& Co., London 1902.

FREMONT-BARNES, Gregory, Nile 1798: Nelson's First Great Victory, Illustrated by H. Gerrard, Osprey Publishing, Oxford 2011.

FREY, Linda S., FREY, Marsha L., The French Revolution, Greenwood Publishing Group, Westport 2004.

GARDINER, Samuel Rawson, A Student's History of England from the Earliest Times to 1885, Longmans, Green, and Co., London, New York 1892.

The History of Nations England, Edited by Augustus Hunt Shearer, Vol. XI, P. F. Collier \& Son Publishers, New York 1913.

GLEICHEN, Edward, France: The Nations of Today, A New History of the World, Edited by John Buchan, Hodder and Stoughton, London 1923.

GREEN, John Richard, World's Best Histories England, With a Supplementary Chapter of Recent Events by Julian Hawthorne, Vol. IV, Co-operative Publication Society, New York and London, 1898.

GRIMSHAW, William, History of England, Grigg, Elliot \& Co., Philadelphia 1847.

GUIZOT, M.; WITT, Madame Guizot, France, Translated By Robert Black, Vol. VI, Peter Fenelon Collier \& Son, New York 1900.

HARDING, Richard, "Neglect or Treason: Leadership Failure in the Mid-EighteenthCentury Royal Navy", Naval Leadership and Management, 1650-1950: Essays in Honour of Michael Duffy, Edited by Helen Doe and Richard Harding, Boydell Press, UK 2012, s. 43-60.

HAZEN, Charles Downer, The French Revolution and Napoleon, Henry Holt and Company, New York 1917.

HEADLAM, Cecil, The Making of Nations France, Adam \& Charles Black, London 1913.

HEFFERNAN, Michael, "France and the Wider World", Revolutionary France 17881880, The Short Oxford History of France, Edited by Malcolm Crook, Oxford University Press, New York 2002, s. 178-206.

HENTY, George Alfred, At Aboukir and Acre: A Story of Napoleon's Invasion of Egypt, Charles Scribner's Sons, New York 1898.

HEROLD, J. Christopher, Bonaparte in Egypt, Harper \& Row, New York 1962.

https://en.oxforddictionaries.com/definition/nelson touch

https://www.thegazette.co.uk/about

HUGHES, Thomas Smart, The History of England From the Accession of George III. 1760 to the Accession of Queen Victoria 1837, Vol. VI, Third Edition, George Bell, London 1846. 
Yahya BAĞÇECI

HUNT, William, The History of England from the Accession of George III to the Close of Pitt's First Administration (1760-1801), Longmans, Green, and Co., London, New York and Bombay 1905.

JAMES, William, The Naval History Of Great Britain, From the Declaration of War by France in 1793, to the Accession of George IV, Vol. II, Richard Bentley, London $\underline{1837 .}$

JERVIS, William Henley, A History of France, Harper \& Brothers, New York 1876.

KARAL, Enver Ziya, Osmanlı Tarihi, Nizam-ı Cedid ve Tanzimat Devirleri (1789-1856), Cilt V, Türk Tarih Kurumu Yayınları, Ankara 1988.

KEEGAN, John, Intelligence In War - Knowledge of the Enemy from Napoleon to AlQaeda, Pimlico, 2004.

KITCHIN, George William, A History of France, Vol. III, Clarendon Press, Oxford 1877.

KNIGHT, Roger, Britain Against Napoleon: The Organization of Victory, 1793-1815, Penguin Books, London 2013.

, The Pursuit of Victory: The Life and Achievement of Horatio Nelson, Basic Books, New York 2005.

LAMBERT, Andrew, Nelson: Britannia's God of War, Faber \& Faber, 2010.

LAVERY, Brian, Nelson and the Nile: The Naval War Against Bonaparte 1798, Caxton Editions, UK 2003.

Life of William Pitt, Late Prime Minister of Great Britain: With Biographical Notices of His Principal Friends and Illustrious Contemporaries, John Watts, Philadelphia 1806.

MACKESY, Piers, British Victory in Egypt, 1801: The End of Napoleon's Conquest, Routledge London and New York 1995.

MAHAN, Alfred Thayer, The Influence of Sea Power upon the French Revolution and Empire 1793-1812, Vol. I, Sampson Low, Marston \& Company, London 1892.

The Life of Nelson: The Embodiment of the Sea Power of Great Britain, Vol. I, Sampson Low, Marston \& Company, London 1897.

Naval Leadership and Management, 1650-1950: Essays in Honour of Michael Duffy, Edited by Helen Doe and Richard Harding, Boydell Press, UK 2012.

NEELY, Sylvia, A Concise History of the French Revolution, Rowman \& Littlefield, Plymouth 2008.

Nelson against Napoleon: From the Nile to Copenhagen, 1798-1801, Edited by Robert Gardiner, Caxton Editions, London 2001.

Nelson the New Letters, Edited by Colin White, The Boydell Press, Suffolk-New York 2005.

ÖZKOÇ, Özge, Imparatorluk İktidarının Sinırında Osmanlı Mısırı: Mehmet Ali Paşa Döneminden Hidivliğe, Doktora Tezi, Ankara Üniversitesi Sosyal Bilimler Enstitüsü Uluslararası İlişskiler Anabilim Dalı, Ankara 2013.

POCOCK, Nicholas, PY7942-Royal Museums Greenwich http://images.rmg.co.uk 
ROBSON, Martin, History of the Royal Navy, The Napoleonic Wars, I. B. Tauris, London 2014.

RODGER, N. A. M., The Command of the Ocean: A Naval History of Britain 1649-1815, W. W. Norton Company, New York London, 2005.

ROSS, Stewart, Events and Outcomes: The French Revolution, Evans Brothers, London 2002.

RUDÉ, George, The French Revolution, Grove Press, New York 1991.

SAID, Edward W., Şarkiyatçılık, Batı'nın Şark Anlayışları, Çeviren: Berna Ülner, Metis Yayınlar1, İstanbul 1999.

SOUTHEY, Robert, The Life of Horatio Lord Nelson, J. M. Dent \& Co., E. P. Dutton \& Co., London and New York 1906.

STRATHERN, Paul, Napoleon in Egypt, Random House Publishing Group, London 2008.

SUGDEN, John, Nelson: A Dream of Glory, Henry Holt and Company, New York 2004.

THOMPSON, Edith, History of England, James Campbell and Son, Toronto 1878.

THOYRAS, Rapin, The History of England from the Earliest Periods, Vol. II, Translated, Corrected and Revised and Continued to the Present Time by Henry Robertson, Albion Press, Printed for J. and J. Cundee, London 1820.

TRACY, Nicholas, Nelson's Battles: The Triumph of British Seapower, Seaforth Publishing, Barnsley UK 2008.

TUCKER, Spencer C., Battles that Changed History: An Encyclopedia of World Conflict, ABC-CLIO, Santa Barbara, Denver, Oxford 2011.

WARNER, Oliver, Nelson's Battles: The Triumph of British Seapower, Pen and Sword Military Classics, S. Yorkshire 2003. , The Battle of the Nile, Pickle Partners Publishing, 2017.

WILSON, Kathleen, "Nelson, and the People: Manliness, Patriotism and Body Politics", Admiral Lord Nelson: Context and Legacy, Edited by David Cannadine, Palgrave Macmillan, Hampshire and New York 2005, s. 49-66.

WINFIELD, Rif, British Warships in the Age of Sail 1793-1817: Design, Construction, Careers and Fates, Seaforth Publishing, South Yorkshire 2008. 